\title{
Consequences and Mechanisms of Spike Broadening of R20 Cells in Aplysia californica
}

\author{
Minghong $\mathrm{Ma}^{1,3,4}$ and John Koester ${ }^{1,2,4}$ \\ ${ }^{1}$ Center for Neurobiology and Behavior, ${ }^{2}$ Department of Psychiatry, and ${ }^{3}$ Department of Physiology and Cellular \\ Biophysics, College of Physicians and Surgeons, Columbia University, and ${ }^{4}$ The New York State Psychiatric \\ Institute, New York, New York 10032
}

\begin{abstract}
We studied frequency-dependent spike broadening in the two electrically coupled R20 neurons in the abdominal ganglion of Aplysia. The peptidergic R20 cells excite the R25/ L25 interneurons (which trigger respiratory pumping) and inhibit the RB cells. When fired at $1-10 \mathrm{~Hz}$, the duration of the falling phase of the action potential in R20 neurons increases 2-10-fold during a spike train.

Spike broadening recorded from the somata of the R20 cells affected synaptic transmission to nearby follower cells. Chemically mediated synaptic output was reduced by approximately $50 \%$ when recorded trains of nonbroadened action potentials were used as command signals for a voltage-clamped R20 cell. Electrotonic EPSPs between the R20 cells, which normally facilitated by two- to fourfold during a high frequency spike train, showed no facilitation when spike broadening was prevented under voltage-clamp control.
\end{abstract}

To examine the mechanism of frequency-dependent spike broadening, we applied two-electrode voltage-clamp and pharmacological techniques to the somata of R20 cells. Several voltage-gated ionic currents were isolated, including $I_{\text {Na }}$ a multicomponent $I_{\mathrm{Ca}}$, and three $\mathrm{K}^{+}$currentsa high threshold, fast transient A-type $\mathrm{K}^{+}$current $\left(I_{\text {Adepol }}\right)$, a delayed rectifier $\mathrm{K}^{+}$current $\left(I_{\mathrm{K}-\mathrm{v}}\right)$, and a $\mathrm{Ca}^{2+}$-sensitive $\mathrm{K}^{+}$ current $\left(l_{\mathrm{K}-\mathrm{Ca}}\right)$, made up of two components. The influences of different currents on spike broadening were determined by using the recorded train of gradually broadening action potentials as the command for the voltage clamp. We found the following. (1) $I_{\text {Adopo }}$ is the major outward current that contributes to repolarization of nonbroadened spikes. It undergoes pronounced cumulative inactivation that is a critical determinant of spike broadening. (2) Activity-dependent changes in $I_{\mathrm{K}-\mathrm{v}}, I_{\mathrm{K}-\mathrm{Ca}}$, and $I_{\mathrm{Ca}}$ have complex effects on the kinetics and extent of broadening. (3) The time integral of $I_{\mathrm{Ca}}$ during individual action potentials increases approximately threefold during spike broadening.

[Key words: spike broadening, transmitter release, $\mathrm{K}^{+}$ channels, $\mathrm{Ca}^{2+}$ channels, voltage clamp, Aplysia]

\footnotetext{
Received Mar. 30, 1995; revised June 5, 1995; accepted June 8, 1995.

We thank Dr. Jess Ting for help in the initial stages of this work, and I. Kupfermann, A. MacDermott, and S. Siegelbaum for comments on an earlier draft of this article. This work was supported by NIH Grant NS14385.

Correspondence should be addressed to Dr. John Koester, Center for Neurobiology and Behavior, NYS Psychiatric Institute, 722 West 168th Street, New York, NY 10032.

Copyright (C) 1995 Society for Neuroscience 0270-6474/95/156720-15\$05.00/0
}

The phenomenon of spike broadening is of fundamental importance to neuronal functioning for three reasons. First, an increase in spike duration may increase the probability of conduction at regions of low safety margin for conduction (Westerfield et al., 1978). Second, the low-pass filtering properties of electrical synapses make them sensitive to presynaptic spike duration (Bennett, 1966). Third, an increase in presynaptic action potential duration may increase $\mathrm{Ca}^{2+}$ influx through voltage-gated ion channels (Augustine, 1990), and the resultant increase in cytoplasmic free $\mathrm{Ca}^{2+}\left(\left[\mathrm{Ca}^{2+}\right]_{i}\right)$ may in turn regulate various cellular processes (Clapham, 1995), including neurotransmitter release (Zucker, 1993).

The effects of spike broadening on $\mathrm{Ca}^{2+}$ influx and on transmitter release have been widely studied. A positive correlation has been found between spike width and release in a variety of preparations (e.g., Mudge et al., 1979; Gillette et al., 1980; Coates and Bulloch, 1985; Lin and Faber, 1988). In several preparations, spike broadening has been correlated with a rise in intracellular $\mathrm{Ca}^{2+}$ and an increase in transmitter release (Katz and Miledi, 1967; Augustine, 1990; Bourque, 1991; Jackson et al., 1991; Eliot et al., 1993). However, prolonged action potentials are not always associated with greater $\mathrm{Ca}^{2+}$ influx or enhanced transmitter release (Smith and Zucker, 1980; Spencer et al., 1989). Thus, the effects of spike broadening on $\mathrm{Ca}^{2+}$ influx and on transminter release are diverse.

Frequency-dependent spike broadening, defined as an endogenously generated increase in spike duration that increases as a function of firing rate, is unusually pronounced in the somata of the two R20 neurons in the abdominal ganglion of Aplysia. These twin R20 cells, which are electrically coupled to each other, appear to be identical in all of their anatomical and functional properties. They contain the neuropeptides $\mathrm{SCP}_{\mathrm{A}}$ and $\mathrm{SCP}_{\mathrm{B}}$ and are thought to be peptidergic. Some of their postsynaptic follower cells, such as the R25 and the RB cell clusters, are located quite close to the R20 cells (Alevizos et al., 1989), and transmitter release by the R20 cell output terminals can be affected by changes in action potential shape generated in the soma (see below). Thus, the connections of the R20 cells to RB cells and to R25 cells provide an excellent system with which to study the role of frequency-dependent spike broadening in modulating both $\mathrm{Ca}^{2+}$ influx and synaptic transmission, as well as the mechanisms of spike broadening.

A major goal of this study was to address the general question of how the unique mixture of different types of membrane ion channels expressed in a given type of neuron combine to endow that neuron with unique functional properties. We used selective 
pharmacological blockers to isolate various ionic currents in the R20 cells. This conventional approach was combined with a method in which the command to the voltage-clamp circuit consisted of the waveforms of endogenously generated action potentials recorded separately under current clamp. In this way we were able to test the effects of frequency-dependent spike hroadening on chemical and electrical synaptic transmission, record the $\mathrm{Ca}^{2+}$ current $\left(I_{\mathrm{Ca}}\right)$ from the presynaptic cells during the action potential train, and determine the ionic mechanisms of spike broadening in the same preparation. Although the changes in ionic currents underlying frequency-dependent broadening of spikes were recorded from the somata of R20 cells, the results are consistent with the hypothesis that similar processes may occur at or near their presynaptic terminals.

We found that a current called $I_{\text {Adcpal }}$ plays a critical role in spike broadening in these neurons. $I_{\text {Adepol }}$, which is a fast transient, A-type $\mathrm{K}^{+}$current, has two key distinguishing properties: it is activated and inactivated at more depolarized potentials and it is more easily blocked by 4-aminopyridine (4-AP) than other A currents in Aplysia (Furukawa et al., 1992). The gene encoding the channel that conducts $I_{\text {Adepol }}$, (AKV1.1a), has been cloned recently by Pfaffinger et al. (1991). Kaang et al. (1992) showed that expressing high levels of the $I_{\text {Adepol }}$ channel in a neuron that normally does not express it causes a decrease in transmitter release by shortening spike duration. The functional significance of the endogenous expression of this current had not been determined, however. We found that in the R20 neurons, cumulative inactivation of $I_{\text {Adepol }}$ during a spike train is essential for frequency-dependent spike broadening. Other currents that change secondarily, affecting the kinetics and maximum extent of broadening, include $\mathrm{Ca}^{2+}$ current $\left(I_{\mathrm{Ca}}\right)$, a Ca ${ }^{2+}$-sensitive potassium current $\left(I_{\mathrm{K}-\mathrm{Ca}_{\mathrm{a}}}\right)$, and a delayed rectifier current $\left(I_{\mathrm{K}-\mathrm{V}}\right)$. The broadening that occurs during a spike train enhances both electrical and chemical synaptic transmission, and is accompanied by an increase in the time integral of $I_{\mathrm{Ca}}$ in the presynaptic R20 cell.

\section{Materials and Methods}

Preparations. Specimens of Aplysia californica weighing from 50-350 gm were supplied by Marinus (Long Beach, CA). Animals were maintained in an aquarium of artificial sea water (ASW) at $15^{\circ} \mathrm{C}$ before use. Each animal was anesthetized by injection with isotonic $\mathrm{MgCl}_{2}$ before the abdominal ganglion was dissected out. It was bathed in ASW containing $0.5 \%$ glutaraldehyde for $45 \mathrm{sec}$ before desheathing to reduce the contraction of the sheath during recording. In some preparations, the distal genital or branchial nerve was dissected out as far as $2-5 \mathrm{~cm}$ from the ganglion in order to record the action potential in R20's axon with an extracellular electrode. The ganglion was pinned to the elastomer (Sylgard, Dow-Corning) bottom of an experimental chamber with a volume of $0.5 \mathrm{ml}$, which was filled with ASW. The chamber was maintained at $15-17^{\circ} \mathrm{C}$ by using a cooling plate, except as described below. The R20 cells, R15 and the RB cells were identified as described previously (Frazier et al., 1967; Alevizos et al., 1989). Four methods were used to improve the space clamp of the somata of thesc cells: (1) the main axon branches were truncated by cutting the branchial nerve and the commissure between the two hemi-ganglia very short; or (2) the proximal axon of R20 was ligated with a fine thread; (3) in some experiments (see Fig. $5 D$ ) in which rapidly activating sodium difference currents were recorded, the current was slowed by cooling the preparation to $10^{\circ} \mathrm{C}$; (4) in most experiments in which individual currents were measured by using blocking drugs to isolate difference currents, other nonrelevant currents were preblocked with other compounds, to enhance the cell's length constant. Although these precautions were generally adequate, in some cases slight deviations from space clamp were revealed by the presence of small, late responses in the current traces, presumably arising from proximal axon stumps that were imperfectly clamped. These small deviations from space clamp are unlikely to affect the conclusions drawn from the data.

Electrophysiology. The R20 cells were voltage clamped by a conventional two-microelectrode method, using an Axoclamp-2A (Axon Instruments Inc., Foster City, CA). The voltage-recording electrode was filled with $2 \mathrm{M} \mathrm{KCl}$ and the current-passing electrode contained $2 \mathrm{M}$ potassium acetate. In some experiments, a third electrode, filled with 2 $\mathrm{M} \mathrm{KCl}$, was used to record intracellularly from RB cells. In a few preparations, an extracellular electrode cuff was used to record en passant from the genital or branchial nerve (Alevizos et al., 1991). All voltage signals from intracellular or extracellular electrodes were recorded with a digital tape recorder (PCM Data Recorder, A. R. Vetter Co., Rebersburg, PA), which has a sampling rate of $22 \mathrm{kHz}$ per channel. Voltage and current data from voltage-clamp experiments were acquired and analyzed using a Tangent 486 computer and PCLAMP 6.0 .2 software (Axon Instruments Inc.) with a sampling rate of $20 \mathrm{kHz}$ for each channel. The current traces were filtered by a single pole low pass $\mathrm{RC}$ filter at either $500 \mathrm{~Hz}$ or, in one case, $1 \mathrm{KHz}$ (see Fig. 6 caption). Series resistance, which fell in the range of $6-10 \mathrm{k} \Omega$, was not compensated. We used $7-8 \mathrm{~Hz}$ stimulation in most experiments, to maximize the speed of spike broadening.

Conventional rectangular voltage pulses, combined with pharmacological blockers, were used to identify the major voltage-gated currents in the R20 cells. To identify how individual currents change during an action potential train, we used recorded action potentials as the command for the voltage clamp. This method has been described by others (e.g., Starzak and Starzak, 1978; Llinas et al., 1982; Gola et al., 1986; Scroggs and Fox, 1992). In short, under current clamp we tape-recorded a train of gradually broadening action potentials with the ganglion bathed in normal ASW. The spikes were evoked by the injection of a train of brief stimulating current pulses. We also recorded a train of trigger pulses synchronized to the current pulses. Then, with the cell voltage-clamped, the two trains were played back simultaneously: the action potential train as the command signal for the voltage clamp and the trigger pulses for initiating episodes of data acquisition for the membrane current and voltage recordings. In each experiment, the action potential train used as the command was recorded from the same cell that was later voltage clamped. In normal ASW the total membranc current flowing through the clamp circuit during an action potential command (control current) should be null, except for the stimulating current pulses; all the remaining current required to change the charge on the membrane capacitance flows through the voltage-gated membrane ion channels that gave rise to the orignal action potential (Starzak and Starzak, 1978). Data selected for analysis were limited to preparations in which this criterion was met with only minor deviations. When the command was repeated after adding a specific channel blocker to the bath, a net current was generated by the clamp during the command. The difference currents obtained by subtracting the currents with blocker from the control currents gave the waveforms of the specific currents that contributed to action potential generation in currentclamp mode.

In experiments to determinte the effect of spike broadening on synaptic transmission, the entire action potential train initiated in currentclamp mode was digitized and recorded on disk as well as on tape. Then, in voltage-clamp mode, the recorded spikes were used to generate two alternative versions of a spike train that were used to drive the R20 cell. Either (1) the entire train of gradually broadening spikes, played back directly off the tape, was used as the command for the clamp, or (2) the nonbroadened, first spike in the train, from the version stored on disk, was played back repeatedly to generate an artificial spike train as the command. The holding potential between spikes was the same as the cell's resting potential.

Pharmacology. The following compounds were used to block various currents: tetrodotoxin (TTX) (Calbiochem, San Diego, CA), purified charybdotoxin (ChTX) (Alomone Labs, Jerusalem, Israel), synthetic ChTX (LC Laboratories, Woburn, MA), crude ChTX from Leiurus q. hebraeus (Accurate Chemical Corp, Westbury, NY), kaliotoxin (KTX) (Accurate Chemical Corp.), 1,2-bis(2-aminophenoxy)ethane- $N, N, N^{\prime}, N^{\prime}$ tetracetic acid (BAPTA) tetrapotassium salt (Molecular Probes Inc., Eugene, OR), $\omega$-agatoxin IVa ( $\omega$-Aga IVa) (Pfizer Research Inc., Groton, $\mathrm{CT}), \mathrm{CdCl}_{2}$, nifedipine, potassium ethyleneglycol-bis-( $\beta$-aminoethyl ether) $N, N^{\prime}$-tetra-acetic acid (EGTA), 4-aminopyridine (4-AP), tetraethylammonium chloride (TEA), and $\omega$-conotoxin GVIA ( $\omega$-CgTX) (Sigma Chemical Co., St. Louis, MO).

In most experiments, a compound was applied by injecting a con- 


\section{$1 \mathrm{~Hz}$}

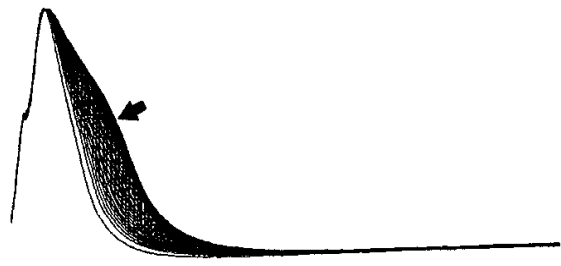

$3 \mathrm{~Hz}$

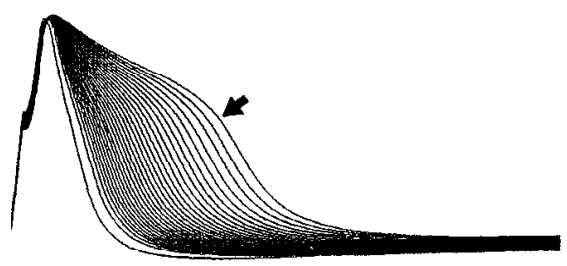

$6 \mathrm{~Hz}$

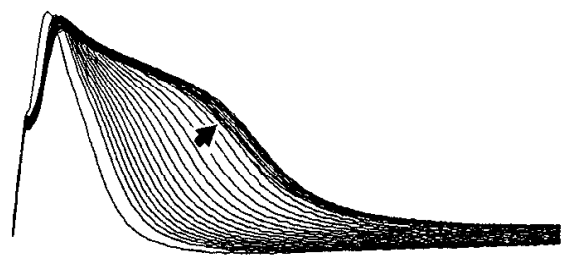

$2 \mathrm{~Hz}$

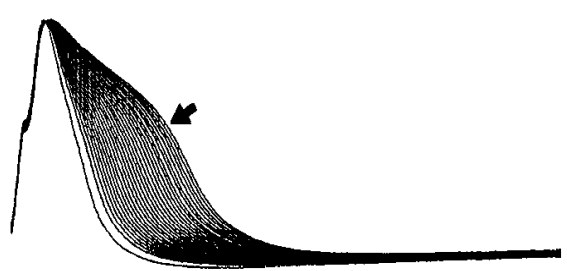

$4 \mathrm{~Hz}$

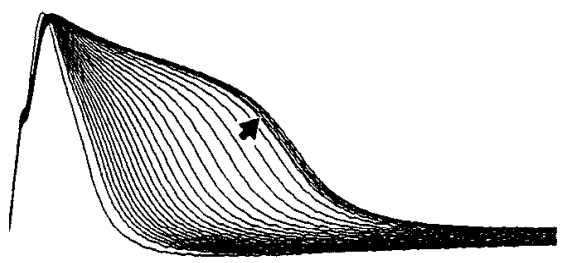

$8 \mathrm{~Hz}$

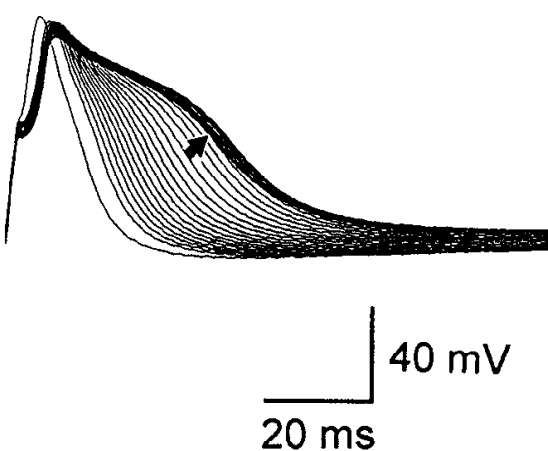

Figure 1. Action potentials recorded from the soma of an R20 cell exhibit pronounced frequency-dependent broadening. In current-clamp mode, 60 action potentials were evoked by injecting brief depolarizing current pulses into the soma of an R20 cell at different frequencies. Every other spike is shown here. The arrows indicate the last spike during each train. The resting potential was $-45 \mathrm{mV}$.

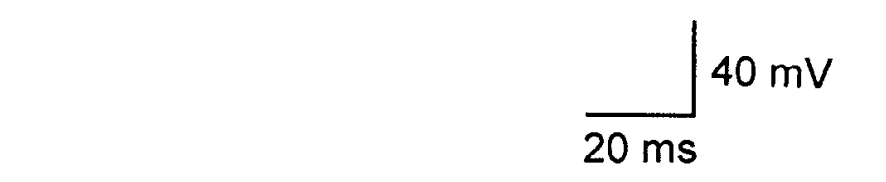

centrated bolus into the recording chamber directly by pipette. To block $I_{\mathrm{K}-\mathrm{Ca}}$, EGTA or BAPTA was iontophoresed into cells from a third electrode filled with $0.1 \mathrm{M}$ EGTA $(\mathrm{pH}=7.2)$ or $0.2 \mathrm{M}$ BAPTA with the cell under voltage clamp (Crest and Gola, 1993).

The composition of ASW was as follows (in mM): $460 \mathrm{NaCl}, 10 \mathrm{KCl}$, $11 \mathrm{CaCl}_{2}, 55 \mathrm{MgCl}_{2}, 2.5 \mathrm{NaHCO}_{3}$, 10 Tris(hydroxymethyl)aminomethane and Tris hydrochloride (Tris, $\mathrm{pH}=7.6$ ). $\mathrm{Ba}^{2+}-\mathrm{ASW}$, used for enhancing currents through $\mathrm{Ca}^{2+}$ channels in some experiments, contained 450 TEACl, $10 \mathrm{KCl}, 11 \mathrm{BaCl}_{2}, 55 \mathrm{MgCl}_{2}, 104-\mathrm{AP}$, 10 Tris.

\section{Results}

$R 20$ cells undergo pronounced frequency-dependent spike broadening

The R20 neurons, which are normally silent, exhibit pronounced spike broadening when fired repetitively by sustained depolarization or by brief current pulses injected into the soma. The frequency-dependent spike broadening of one R20 cell is shown in Figure 1, from an experiment in which 60 brief current pulses at different frequencies were injected into the soma. With the cell stimulated at $4 \mathrm{~Hz}$, the duration of the evoked action potential, defined as the time from the peak to the mid-point of the falling phase, increased from $5 \mathrm{msec}$ for the first spike to a maximum of $40 \mathrm{msec}$. Late in the train, spike width decreased slightly. As frequency was increased beyond $4 \mathrm{~Hz}$, the extent of spike broadening decreased. For example, the duration of action potentials increased to a maximum of only $32 \mathrm{msec}$ at $8 \mathrm{~Hz}$. A second effect of increasing frequency was that less spikes were required to reach maximum broadening. For example, it took 50,42 , and 40 spikes to reach the maximum broadening at 4 , 6 , and $8 \mathrm{~Hz}$, respectively. At 2 or $3 \mathrm{~Hz}$, maximum broadening was not reached at the end of the 60 spike train. Prolonging the train produced further broadening, though not as much as when the cell fired at $4 \mathrm{~Hz}$ (data not shown). For most R20 cells, the maximum broadening typically occurred in the spike frequency range of 4-6 Hz. Similar broadening was observed in R20 somata that had been tied off at the proximal axon and also in R20 neurons in dissociated cell culture (unpublished results), suggesting that the broadening is caused not by autaptic or polysynaptic release of transmitters such as SCP, but rather by intrinsic, activity-dependent changes in voltage-gated ion chan- 


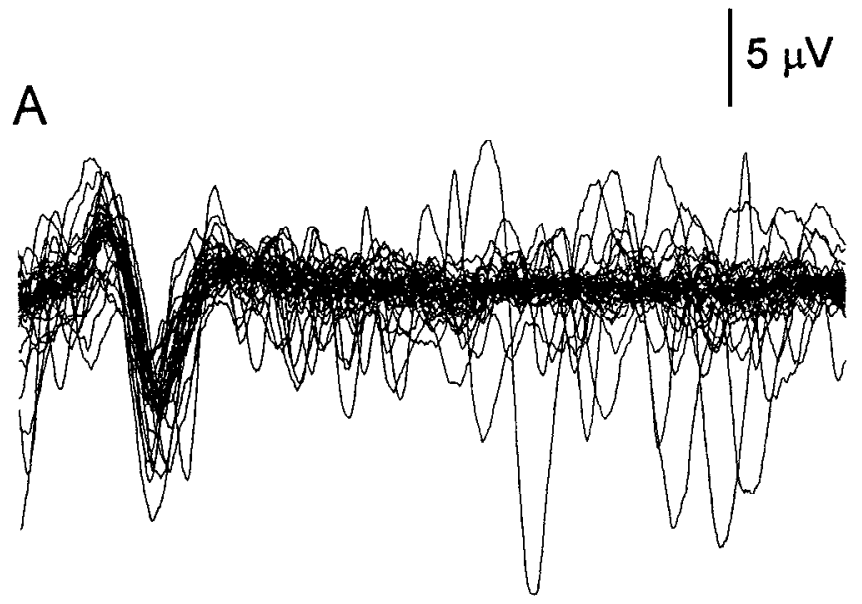

B

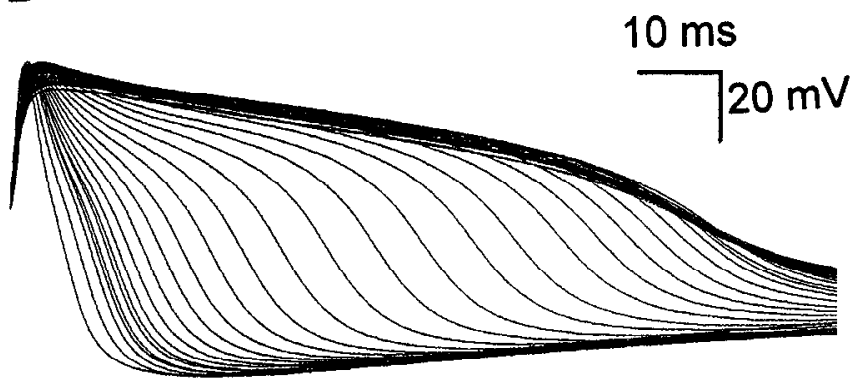

Figure 2. Action potentials recorded from an R20 cell's axon in a peripheral nerve do not exhibit frequency-dependent broadening. A depolarizing DC pulse $(+20 \mathrm{nA}, 10 \mathrm{sec})$ was injected into the soma of an R20 cell. The action potentials from the branchial nerve $(A)$ and the R20 soma $(B)$ were recorded simultaneously. The average frequency of spikes during the train was $2.5 \mathrm{~Hz}$. The resting potential was $-50 \mathrm{mV}$.

nels. Action potentials recorded from R20 axons in either the distal genital or branchial nerve ( $1-4 \mathrm{~cm}$ from the ganglia) failed to show spike broadening in five experiments (Fig. 2).

\section{Spike broadening enhances synaptic transmission}

There are several postsynaptic followers of the R20 cells in the abdominal ganglion that are possible candidates for studying the effects of action potential broadening on transmitter release (Alevizos et al., 1989). The R20 cells excite the R25 and L25 interneuron clusters. The cells in these two clusters form an interconnected network which triggers respiratory pumping by firing an all-or-none, network-wide burst (Byrne, 1983; Koester, 1989). The R20 cells also inhibit the RB cells. The possible effect of spike broadening in R20 cells on synaptic transmitter release was tested by using $\mathrm{RB}$ cells as the follower cells for two reasons. The RB somata are close to those of the R20 cells, so spike broadening recorded from an R20 soma may be able to influence presynaptic events. In addition, the $\mathrm{RB}$ cells receive stereotyped slow, biphasic synaptic potentials each time the R25/ L25 network bursts (Koester, 1989). Thus, an RB cell can provide a read-out of the effect of an $\mathrm{R} 20$ cell on the frequency of $\mathrm{R} 25 / \mathrm{L} 25$ bursts, as well as the direct inhibitory input it receives from the R20 neuron.

To examine the effect of spike broadening on transmitter release, a train of gradually broadening action potentials $(7 \mathrm{~Hz}$,
$10 \mathrm{sec}$ ) of an R20 cell was recorded in current-clamp mode. Then the R20 cell was voltage clamped and the entire recorded train of broadening spikes was played back as the command to the voltage clamp ( $\Gamma i g .3 A I$ ). The synaptic output of the R20 cell produced in this way in a postsynaptic RB cell or in the R25/T.25 cells was the same as that produced under current clamp. However, synaptic output was decreased when, on alternate trials, the command to the voltage-clamped R20 cell consisted of a train of computer-generated nonbroadened spikes (Fig. 3A2), created by playing back the first nonbroadened spike of a train repetitively at the same frequency $(7 \mathrm{~Hz})$ and for the same duration $(10 \mathrm{sec})$ as the original train under current clamp. In the experiment illustrated in Figure $3 A$, the train of broadening spikes produced a longer duration inhibition of the RB cell, more R25/L25 bursts, and a shorter latency to the first R25/ L25 burst, than did the train of nonbroadened spikes. Figure $3 B$ shows the averaged group data obtained using this experimental protocol. In total, the outputs produced by 32 trains of broadening spikes and 32 trains of nonbroadened spikes were measurcd in six animals. The data for cach of the two conditions were averaged for each animal, and then normalized to the average effects produced by the trains of broadening spikes in that animal. Then the averaged data from each of the six animals were combined to give the group data shown in Figure $3 B$. Preventing the spikes of the R20 cells from broadening caused a $60 \%$ decrease in synaptic output compared to that which occurs with normal spike broadening, when the duration of inhibition of RB cells was used as a criterion for synaptic strength, and a $49 \%$ decrease when the number of elicited R25/L25 bursts was measured. The latency to the first R25/L25 burst was increased by $143 \%$ when spike broadening was prevented. All three differences were statistically significant.

A possible explanation for the increase in synaptic output when spikes are allowed to broaden is the gradual change in interspike membrane potential. The hyperpolarizing afterpotentials that follow the spike gradually decrement throughout the spike train when broadening is allowed to occur normally. This is equivalent to a gradual depolarizing shift in resting potential. Shapiro et al. (1980) and Edmonds et al. (1990) have shown that in other neurons in Aplysia a change in resting potential can enhance transmitter release by increasing resting $\mathrm{Ca}^{2+}$ influx. To test whether such a phenomenon could contribute to the enhanced transmission that occurs when broadening is allowed to develop, we measured synaptic output caused by trains of either broadened or nonbroadened spikes at different holding potentials, from -60 to $-40 \mathrm{mV}$, which includes the full range of potentials covered by hyperpolarizing afterpotentials in R20 cells. No significant difference in synaptic efficacy was noted over this range of holding potentials. Thus, the increase in spike duration per se appears to be important for the enhanced transmitter release.

The effect of spike broadening in one R20 cell on electrical transmission to the other R20 cell was also tested, again by using different types of spike trains as the command (Fig. 4). An 18 $\mathrm{sec}, 4 \mathrm{~Hz}$ train of gradually broadening action potentials was evoked by injecting brief current pulses into the soma of one of the two R20 cells ( $220_{A}$ ) in current clamp mode. The electrotonic EPSPs recorded from the other R20 cell $\left(\mathrm{R} 20_{\mathrm{B}}\right)$, which was hyperpolarized to prevent spiking, showed an increase in amplitude and duration when the entire train was sent as a command to the voltage-clamped $\mathrm{R} 2 \mathrm{O}_{\mathrm{A}}$. Facilitation occurred even though the amplitudes of the presynaptic action potentials de- 
A1

A2

\section{Broadening Spikes}

Non-broadened Spikes

R20
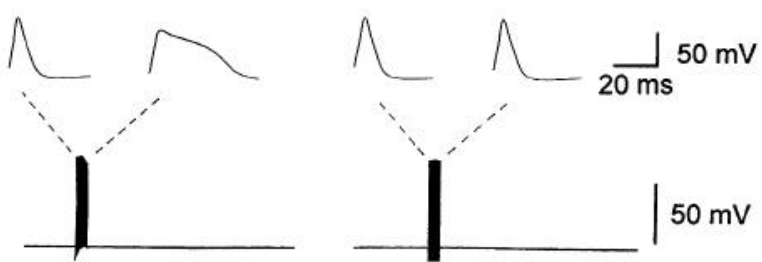

RB

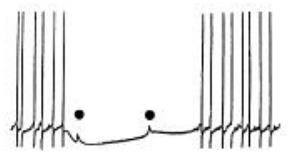

- R25/L25 burst

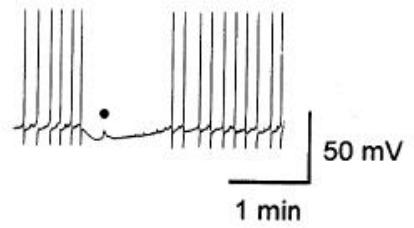

B1

B2
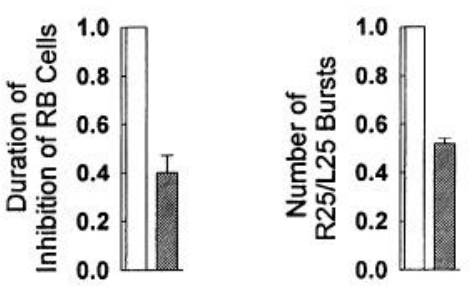

B3

Broadening Spikes

Non-broadened Spikes

Figure 3. Frequency-dependent spike broadening of R20 cells enhances their transmitter release. $A$, Different intensities and durations of synaptic actions were produced in an RB cell when an R20 cell was fired in either a train of broadening spikes $(A l)$ or a train of brief, constant duration spikes (A2). First, a train of broadening spikes, which was evoked by injecting 70 brief depolarizing current pulses (at $7 \mathrm{~Hz}$ ) into the soma of the R20 cell, was recorded in current-clamp mode. Then the recorded spike waveforms were used to generate two kinds of commands that were sent to the voltage-clamped R20: $A 1$, the entire train of broadening spikes was the command, or $A 2$, the first spike in the train was played back repetitively, also at $7 \mathrm{~Hz}$ for $10 \mathrm{sec}$, to generate a train of brief, nonbroadened spikes as the command. The insets show the first and last spikes in each train. The dots indicate the occurrence of bursts in the network of R25/L25 interneurons, monitored by its conjoint excitatory/inhibitory input to the RB cell. The holding potential of the R20 cell was $-40 \mathrm{mV}$. $B$, Averaged group data $(N=$ 6 ), using the protocol illustrated in $A$, shows that preventing spike broadening reduces the effectiveness of chemical transmission. The differences were significantly different (two-tailed $t$ test). The data from each animal were normalized to the effects produced by the trains of broadening spikes. $B 1$, The duration of inhibition of RB cells was $40 \%$ of control $( \pm 7 \%, p<0.001)$ when the trains of nonbroadened spikes were used as the command to the voltage-clamped R20 cells (control was $55.3 \pm 11.6 \mathrm{sec}$ ). Duration was defined as the time from the beginning of R20 stimulation until the the next spike in the RB follwer cell. $B 2$, The number of elicited R25/L25 bursts was $51 \%$ of control $( \pm 2 \%$, $p<0.001$ ) when the trains of nonbroadened spikes were used. [control was $(2.65 \pm 0.27) / 3 \mathrm{~min}]$. B3, The latency to the first R25/L25 burst was $243 \%$ of control $( \pm 32 \%, p<0.001)$ when the trains of nonbroadened spikes were used (control was $9.7 \pm 0.8 \mathrm{sec}$ ). The error bars and \pm values stand for the SEMs.
A

\section{Broadening Spikes}

A1
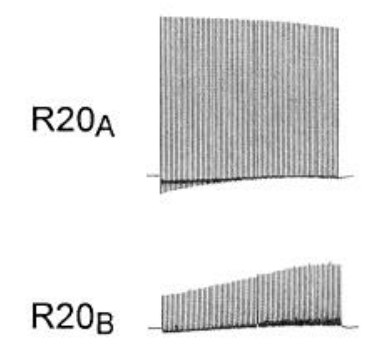

$\uparrow$

B

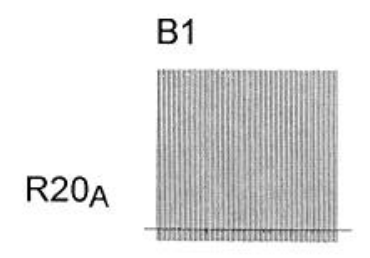

$\mathrm{R} 20_{\mathrm{B}}$

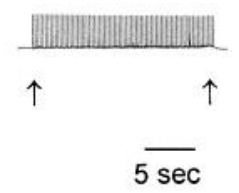

B1
$\mathrm{A} 2$

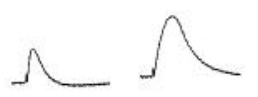

$\uparrow$

$\uparrow$

Non-broadened Spikes

B2
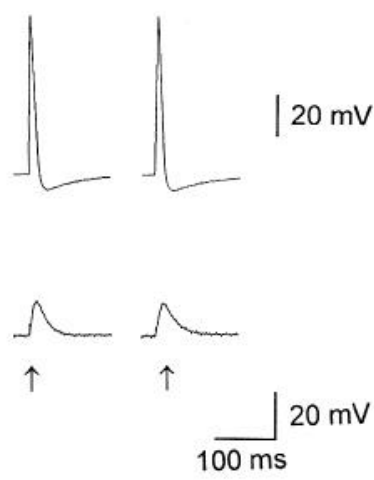

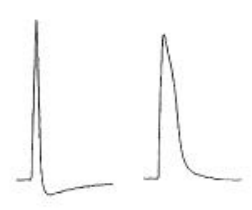

Figure 4. Frequency-dependent spike broadening enhances electrical coupling between R20 cells. A train of gradually broadening action potentials that was elicited by injecting 74 brief, depolarizing current pulses into the soma of $\mathrm{R} 2 \mathrm{O}_{\mathrm{A}}$ at $4 \mathrm{~Hz}$ was recorded. Then two kinds of commands, broadening spikes in $A$ and nonbroadened spikes in $B$, were sent to the voltage-clamped $\mathrm{R} 2 \mathrm{O}_{\mathrm{A}}$. These clamp-driven spikes and the electrotonic PSPs they generated in $\mathrm{R} 20_{\mathrm{B}}$ are shown here. $A 1$, When the whole train of gradually broadening spikes was sent as the command to the voltage-clamped $\mathrm{R} 2 \mathrm{~A}_{\mathrm{A}}$, the electrotonic PSPs facilitated strongly. The first and last spikes and the corresponding EPSPs, marked by arrows, are shown on an expanded time scale in $A 2$. $A 2$, The fivefold broadening of spikes in the presynaptic cell increases both the amplitude and duration of the postsynaptic electrotonic EPSPs. B1, The first spike in the train was played back 74 times at $4 \mathrm{~Hz}$ as the train of nonbroadened spikes to the voltage-clamped $\mathrm{R}_{2} \mathrm{O}_{\mathrm{A}} . \mathrm{B2}$, The first and the last spikes (indicated by arrows) during the train of nonbroadened spikes produced similar electrotonic PSPs in $\mathrm{R}^{2} \mathrm{O}_{\mathrm{B}}$. The holding potential of $\mathrm{R} 20_{\mathrm{A}}$ was $-40 \mathrm{mV}$ and that of $\mathrm{R} 2 \mathrm{O}_{\mathrm{B}}$ was $-58 \mathrm{mV}$.

creased slightly (Fig. 4A). The peak of the EPSP produced by the last broadened spike was increased by $115 \%$ [ $\pm 8 \%$ (SEM), $N=3$ ] when compared to that produced by the first, nonbroadened spike. The net depolarization, expressed as the area under the EPSP, was increased by $328 \%( \pm 21 \%)$. In contrast, when the first (nonbroadened) spike was sent repeatedly as a command to the voltage-clamped $\mathrm{R}^{2} \mathrm{O}_{\mathrm{A}}$ (also at $4 \mathrm{~Hz}$ for $18 \mathrm{sec}$ ), the electrotonic EPSPs in R20 ${ }_{\mathrm{B}}$ did not facilitate (Fig. $4 B$ ).

\section{Changes in several currents determine the pattern of spike} broadening

The R20 cells have five major types of voltage-gated channels. Our first step toward understanding the mechanisms of spike broadening was to pharmacologically separate the different ion 
A

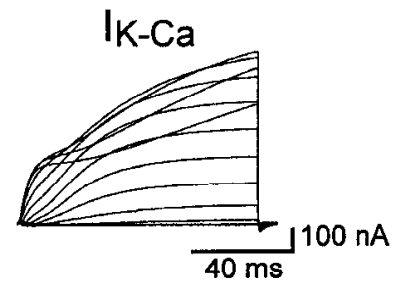

C

IAdepol

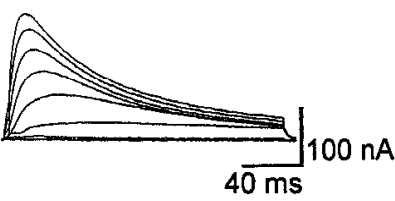

$E$

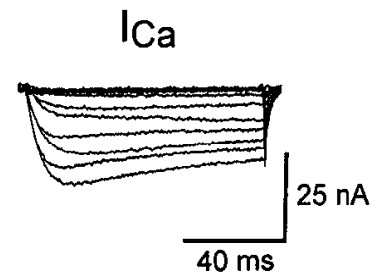

B

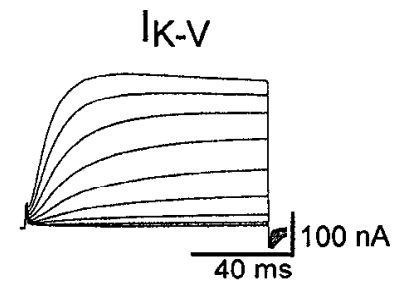

D

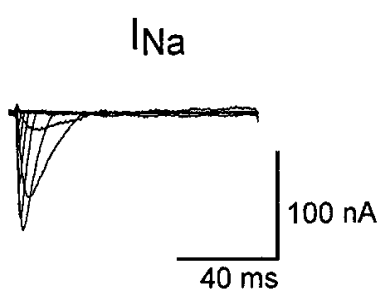

Figure 5. Five voltage-gated ionic currents were isolated in R20 cells by using two-electrode voltage clamp and pharmacological methods. The same voltage-step protocols were performed before and after application of a specific channel blocker. Subtracting the set of currents recorded with the blocker from those recorded without the blocker gave a set of difference currents that could be attributed to a specific channel type. $A, I_{\mathrm{K} . \mathrm{Ca}}$ was isolated by injecting BAPTA intracellularly $(-30 \mathrm{nA}$, $10 \mathrm{~min}$ ) through a third electrode after $60 \mu \mathrm{M}$ TTX had been added to block $I_{\mathrm{Na}}$. The holding potential was $-80 \mathrm{mV}$ and the test pulses were from -40 to $+100 \mathrm{mV} . B, l_{\mathrm{K} . \mathrm{V}}$ was isolated by adding $40 \mathrm{mM}$ TEA after $I_{\mathrm{Ca}}$ and $I_{\mathrm{K}-\mathrm{Ca}}$ had been blocked by $2 \mathrm{mM} \mathrm{CdCl}_{2}$. The holding potential was $-80 \mathrm{mV}$ and the test pulses were from -40 to $+50 \mathrm{mV}$. $C$, $I_{\text {Adepol }}$ was isolated by adding $1 \mathrm{mM} 4$-AP to the bath after $60 \mu \mathrm{MTTX}$, $50 \mathrm{~mm}$ TEA, and $2 \mathrm{mM} \mathrm{CdCl}$, had been added to block other currents. The holding potential was $-50 \mathrm{mV}$, and the test pulses were from -40 to $+30 \mathrm{mV}$. $D, I_{\mathrm{Va}}$ was isolated by adding $60 \mu \mathrm{M}$ TTX after $\mathrm{K}^{+}$currents had been blocked with $80 \mathrm{~mm}$ TEA and $10 \mathrm{~mm} \mathrm{4-AP}$. The holding potential was $-80 \mathrm{mV}$ and test pulses were from -40 to $+40 \mathrm{mV}$. This experiment was performed at $10^{\circ} \mathrm{C}$ in order to improve space-clamp conditions by slowing down $I_{\mathrm{Na}} . E$, Current flow through $\mathrm{Ca}^{2+}$ channels was isolated by adding $2 \mathrm{mM} \mathrm{CdCl} 2$ to TEA/4-AP/ $\mathrm{Ba}^{2+}$-ASW. The holding potential was $-80 \mathrm{mV}$ and the test pulses were from -70 to +40 $\mathrm{mV}$. Voltage steps were in $10 \mathrm{mV}$ increments for all traces $(A-E)$.

currents in the $\mathrm{R} 20$ cells by using a conventional voltage-clamp protocol. Representative results from experiments with 62 R20 cells are shown in Figure 5.

R20 cells contain three $\mathrm{K}^{+}$currents: $\mathrm{Ca}^{2+}$-sensitive $\mathrm{K}^{+}$current $\left(I_{\mathrm{K}-\mathrm{C} \mathrm{a}}\right)$, delayed rectifier current $\left(I_{\mathrm{K}-\mathrm{V}}\right)$, and a high threshold transient $\mathrm{K}^{+}$current $\left(I_{\text {Adepol }}\right)$. In an effort to isolate $I_{\mathrm{K}-\mathrm{Ca}}$, charybdotoxin (either purified, synthetic, or a crude preparation) was used in various experiments. Partially purified charybdotoxin (ChTX) had previously been described to block $I_{\mathrm{K}-\mathrm{Ca}}$ in neuron R15 of Aplysia (Herman and Erxlcben, 1987). Nonc of the forms of ChTX we tried inhibited $I_{\mathrm{K}-\mathrm{Ca}}$, either in R15 or in the R20 cells, at concentrations up to $400 \mathrm{nM}$. Kaliotoxin, a peptide that blocks $I_{\mathrm{K}-\mathrm{Ca}}$ in Helix neurons (Crest et al., 1992), also was ineffective in Aplysia R20 cells, at concentrations up to $500 \mathrm{nM}$. We were able to isolate $I_{\mathrm{K}-\mathrm{Ca}}$ by iontophoresing the $\mathrm{Ca}^{2+}$ buffers EGTA or BAPTA intracellularly (Fig. 5A). Blockade of $I_{\mathrm{K}-\mathrm{Ca}}$ was judged to be complete when further injection of EGTA or BAPTA did not cause additional changes in net current. The resulting difference currents revealed an $I_{\mathrm{K}-\mathrm{Ca}}$ with a hiphasic waveform, suggesting that R20 generates at least two temporal components of $I_{\mathrm{K}-\mathrm{Ca}}$ (Fig. 5A). The two kinetic phases of $I_{\mathrm{K}-\mathrm{Ca}}$ (see Figs. 5A, 9) may result from two different types of channels (Deitmer and Eckert, 1985; Kehoe, 1985; Walsh and Byrne, 1989), or from two populations of the same type of channel that are differentially segregated with respect to the voltage-gated $\mathrm{Ca}^{2+}$ channels (Gola et al., 1990; Crest and Gola, 1993; Gola and Crest, 1993).

Difference currents generated by using 40-50 mM TEA revealed the waveforms of $I_{\mathrm{K}-\mathrm{v}}$ (Fig. $5 B$ ). Because these concentrations of TEA also block $I_{\mathrm{K}-\mathrm{Ca}}$ (Herrman and Gorman, 1981a), the cell was pretreated with $2 \mathrm{mM} \mathrm{CdCl}_{2}$ to eliminate $I_{\mathrm{K}-\mathrm{Ca}}$ by blocking $\mathrm{Ca}^{2+}$ influx. Control experiments showed that $40 \mathrm{~mm}$ TEA blocks approximately $90 \%$ of $I_{\mathrm{K}-\mathrm{v}}$, and Furukawa et al. (1992) had shown that concentrations of TEA as high as $50 \mathrm{~mm}$ has no effect on $I_{\text {Adepol. }}$ So by using 40-50 mM TEA, we achieved close to complete block of $I_{\mathrm{K}} \mathrm{v}$ while minimizing the possibility of nonspecific effects on $I_{\text {Adepol }}$. Control experiments showed that the $\mathrm{Cd}^{2+}$ used to preblock $I_{\mathrm{K}-\mathrm{Ca}}$ completely blocked $I_{\mathrm{Ca}}$, and had no nonspecific effects on $I_{\mathrm{K} \cdot \mathrm{V}}$.

Three types of A currents have been described by Furukawa et al. (1992) in various Aplysia neurons: $I_{\text {Afast }}, I_{\text {Aslow }}$, and $I_{\text {Adepol }}$. They observed $I_{\text {Afast }}$ and $I_{\text {Aslow }}$ when the membrane potential was stepped to potentials more positive than $-50 \mathrm{mV}$ from a holding potential of $-100 \mathrm{mV}$, but not from a holding potential of -50 $\mathrm{mV}$. Thus, they attributed the difference currents generated by switching between holding potentials at $-100 \mathrm{mV}$ and at -50 $\mathrm{mV}$ to $I_{\text {Afast }}$ and $I_{\text {Aslow }}$ (Furukawa et al., 1992). In contrast, they found that $I_{\text {Adepol }}$ can be activated from holding potentials as positive as $-50 \mathrm{mV}$. Using these variable effects of holding potential as a criterion, we found that R20 cells do not generate $I_{\text {Afast }}$. In some cells we detected a small $I_{\text {Aslow }}$ component that was less than $20 \%$ of $I_{\text {Adepol }}$ at a membrane potential where both sets of conductances were maximally activated (data not shown). This component was not examined further, as it is largely inactivated in the range of membrane potentials covered by the spike trains used in this study.

$I_{\text {Adepol }}$ was found to be the major A current in R20 cells. Like the $I_{\text {Adepol }}$ described in other Aplysia neurons, it is highly sensitive to block by 4-AP and relatively insensitive to TEA (Furukawa et al., 1992). This latter characteristic helps to distinguish $I_{\text {Adepol }}$ from another rapidly activating outward current that has been described in the pleural sensory neurons of Aplysia, $I_{\mathrm{K}, \mathrm{V}}$, which is blocked by TEA with an apparent dissociation constant of 6-8 mM (Baxter and Byrne, 1989). $I_{\text {Adcpol }}$ was revealed in our study by adding $1 \mathrm{~mm}$ 4-AP, a dose that had been found by Furukawa et al. (1992) to fully block $I_{\text {Adepol }}$ in other Aplysia neurons. In our experiments, 4-AP was given after $I_{\mathrm{Na}}, I_{\mathrm{Ca}}, I_{\mathrm{K}-\mathrm{V}}$, and $I_{\mathrm{K}-\mathrm{Ca}}$ had been blocked by $60 \mu \mathrm{M}$ TTX, $2 \mathrm{mM} \mathrm{CdCl}$, and $40 \mathrm{mM}$ TEA, to eliminate possible nonspecific effects of 4-AP (Fig. 5C). The difference currents isolated in this way had voltage sensitivity and kinetics (Figs. $5 C$ ) similar to those of the $I_{\text {Adepol }}$ described in neurons R15 and R2 in Aplysia (Furukawa et al., 1992). Given this similarity, plus the fact that Furukawa et al. used $\mathrm{Na}^{+}, \mathrm{Ca}^{2+}$-free solution to block $I_{\mathrm{Na}}$ and $I_{\mathrm{Ca}}$, it is unlikely that the $\mathrm{Cd}^{2+}$ and TTX used in our experiments had major nonspecific effects on $I_{\text {Adepol }}$. 
R20 cells were found to generate both $\mathrm{Na}^{+}$and $\mathrm{Ca}^{2+}$ inward currents. $\mathrm{Na}^{+}$difference currents were isolated by using a supramaximal dose $(60 \mu \mathrm{M})$ of TTX (Geduldig and Gruener, 1970) (Fig. $5 D$ ). Since $\mathrm{Ba}^{2+}$ was found to be a better carrier of current through $\mathrm{Ca}^{2+}$ channels than was $\mathrm{Ca}^{2+}$, we isolated difference currents that flow through $\mathrm{Ca}^{2+}$ channels by applying $2 \mathrm{mM} \mathrm{C.d} \mathrm{d}^{2+}$ to cells that had been bathed in TEA/4-AP/Ba ${ }^{2+}$-ASW (see Materials and Methods), which blocked $I_{\mathrm{Na}}$, as well as the voltagegated $\mathrm{K}^{+}$channels (Fig. $5 E$ ). This concentration of $\mathrm{Cd}^{2+}$ fully blocked $I_{\mathrm{Ca}}$ as judged by the fact that all time-dependent currents were eliminated after adding $\mathrm{Cd}^{2+}$ to the preblocking solution. The $\mathrm{Cd}^{2+}$ difference current appears to be made up of different subtypes, including L-type (blocked by $10 \mu \mathrm{M}$ nifedipine (Edmonds et al., 1990)), N-type (blocked by $10 \mu \mathrm{M}$ $\omega$-CgTX; Trudeau et al., 1993), and P-type (blocked by $2 \mu \mathrm{M}$ $\omega$-Aga IVa (Mintz et al., 1992)) (data not shown). We cannot rule out possible overlap in specificity of these various blockers on different types of $\mathrm{Ca}^{2+}$ channels. However, the effects of nifedipine and $\omega$-Aga IVa were at least partially additive. Moreover, $\omega-\mathrm{CgTX}$ has generally been found to be quite selective for $\mathrm{N}$-type channels in other preparations (McCleskey, 1994). Thus, our results indicate that there may be as many as three subtypes of $I_{\mathrm{Ca}}$.

These specific blockers of $\mathrm{Ca}^{2+}$ channels were also used in an attempt to determine which species of $\mathrm{Ca}^{2+}$ channels mediate the $\mathrm{Ca}^{2+}$ influx that triggers transmitter release. Nifedipine was the most effective of such compounds in blocking $I_{\mathrm{Ca}}$. We found that $10 \mu \mathrm{M} \omega$-conotoxin and $10 \mu \mathrm{M}$ nifedipine, both of which partially block $I_{\mathrm{Ca}}$ in the somata of R20 cells, failed to reduce transmission from the $\mathrm{R} 20$ cells to $\mathrm{RB}$ cells, while $0.5 \mathrm{mM} \mathrm{CdCl}_{2}$ blocked transmission at this synapse completely (data not shown). These data suggest that some kind(s) of $\mathrm{Ca}^{2+}$ currents other than N-type and L-type are responsible for transmitter release, or that each individual $I_{\mathrm{Ca}}$ has a relatively small effect (Fossier et al, 1994). The effect of blocking $\omega$-Aga IVa sensitive $I_{\mathrm{Ca}}$ on transmitter relcase was inconsistent in different preparations, and so remains a possible candidate for triggering transmitter release.

\section{$\mathrm{I}_{N a}$ inactivates only slightly during spike broadening}

In order to study the contributions of different currents to action potential generation and to the shape changes that occur during a spike train, we used a method in which the command to the voltage clamp is an entire train of gradually broadening spikes. Figure 6 shows the raw data from one such experiment. A $7 \mathrm{~Hz}$, $10 \mathrm{sec}$ train of broadening action potentials was tape-recorded in current-clamp mode (Fig. 6A). Then the whole train was sent to the cell as the command in voltage-clamp mode and the membrane current was recorded. As expected, membrane current was zero under control conditions, except for the pulses that correspond to the pulses used under current clamp to trigger the spikes (Fig. 6B). Figure $6 C$ shows the membrane currents recorded after adding $60 \mu \mathrm{M}$ TTX to the bath to block $I_{\mathrm{Na}}$. The TTX difference currents (trace B - trace C) revealed the waveform of $I_{\mathrm{Na}}$ during each spike in the train (Fig. $6 D$ ). The normalized peaks of $I_{\mathrm{Na}}$, time integrals of these traces, and the durations of the spikes during the spike train are plotted in Figure $6 E$. An interesting feature of $I_{\mathrm{Na}}$ was that its duration did not change as successive spike widths increased $(N=6)$. The peaks of $I_{\mathrm{Na}}$ did show a slight cumulative inactivation, so there was slightly less $I_{\mathrm{Na}}$ during later spikes in the train. Because of its rapid kinetics of inactivation, $I_{\mathrm{Na}}$ does not contribute directly to
A
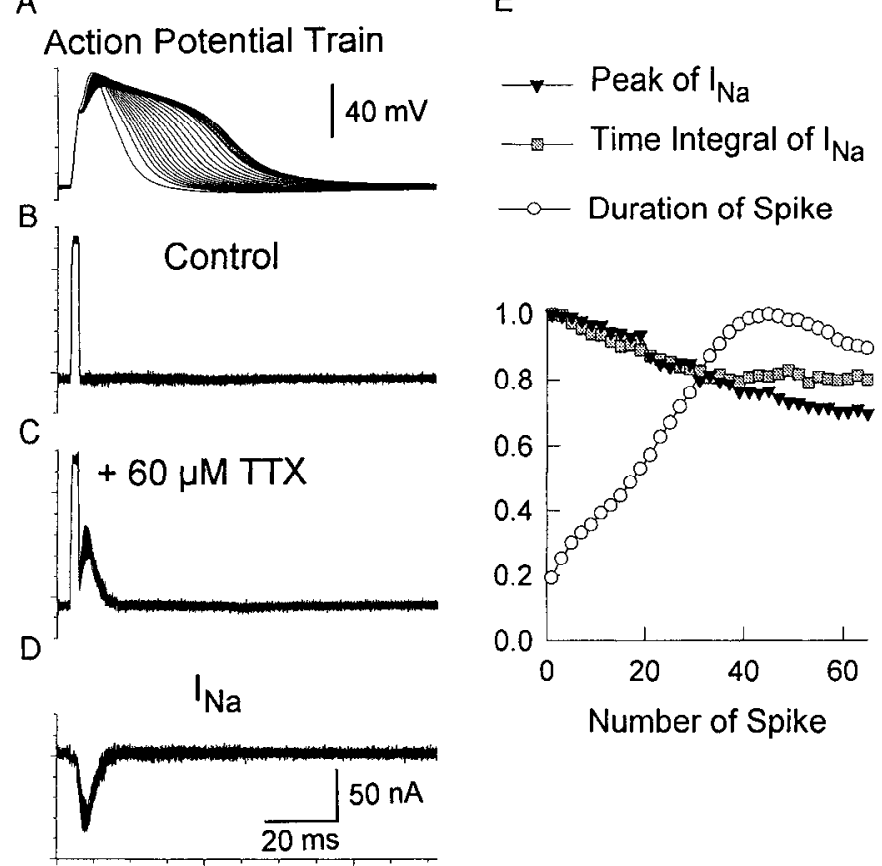

Figure 6. $\mathrm{I}_{\mathrm{Na}}$ inactivates slightly during a train of broadening spikes. $A$, An action potential train $(7 \mathrm{~Hz}, 10 \mathrm{sec})$ was evoked by injecting brief depolarizing current pulses into the soma of the R20 cell in normal ASW. Every other trace is shown here and in subsequent figures that use this protocol. $B$, The current recorded when the entire train of spikes was sent to the voltage-clamped R20 cell in normal ASW had the waveform and amplitude of the stimulating current pulse. $C$, The same protocol as in $B$ was repeated after $60 \mu \mathrm{M}$ TTX had been added to the bath to block $I_{\mathrm{Na}} . D$, Difference currents for $60 \mu \mathrm{M}$ TTX were obtained by subtracting currents in $C^{\prime}$ from currents in $B$, revealing the contribution of $I_{\mathrm{Na}}$ to the action potentials in the train. The holding potential was $-50 \mathrm{mV}$. E , Peaks of $I_{\mathrm{Na}}$, time integrals of $I_{\mathrm{Na}}$, and durations of spikes, normalized to their maximum values, are plotted against spike number.

spike broadening. It may have a small, indirect influence changes in spike width, because the gradual decline in $I_{\mathrm{Na}}$ amplitude contributes to a gradual decrease in spike amplitude and rate of rise, which could have a modest effect on the activation of other currents.

\section{Cumulative inactivation of $\mathrm{I}_{\text {Adepol }}$ is correlated with spike broadening}

The contribution of $I_{\text {Adepol }}$ to frequency-dependent spike broadening was determined by using $1 \mathrm{mM} 4$-AP to generate difference currents. We presume these difference currents represent pure $I_{\text {Adepol }}$, uncontaminated by $I_{\text {Aslow }}$, for two reasons: (1) the holding potential was more positive than $-50 \mathrm{mV}$ where $I_{\text {Aslow }}$ is fully inactivated; and (2) $I_{\text {Aslow }}$ is unaffected by $1 \mathrm{mM} 4-\Lambda \mathrm{P}$ (Furukawa et al., 1992). In our experiments 4-AP was applied after $40 \mathrm{mM}$ TEA had been added to reduce the nonspecific effects of 4-AP on other currents, such as $I_{\mathrm{K}-\mathrm{Ca}}$ and $I_{\mathrm{K} \cdot \mathrm{v}}$ (Hermann and Gorman, 1981a; Brezina, 1988; Howe and Ritchie, 1991). The action potential train recorded in current-clamp mode and the corresponding 4-AP difference currents generated in voltageclamp mode demonstrate that steady, cumulative inactivation of $I_{\text {Adepot }}$ occurs during the spike train (Fig. 7). By the end of the train, $I_{\text {Adepul }}$ transients had decayed almost to zero. Although the simplest interpretation is that the gradual decline of $I_{\text {Adepol }}$ is due 
A
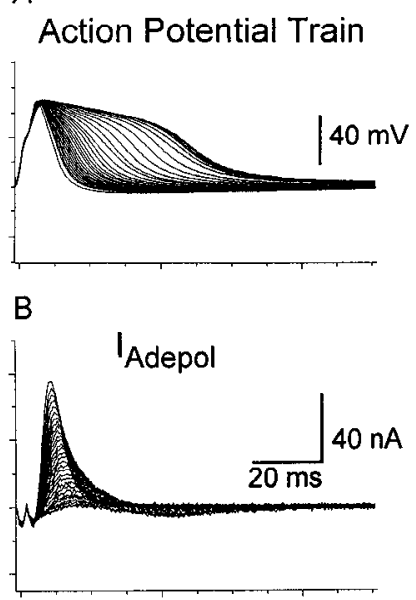

C

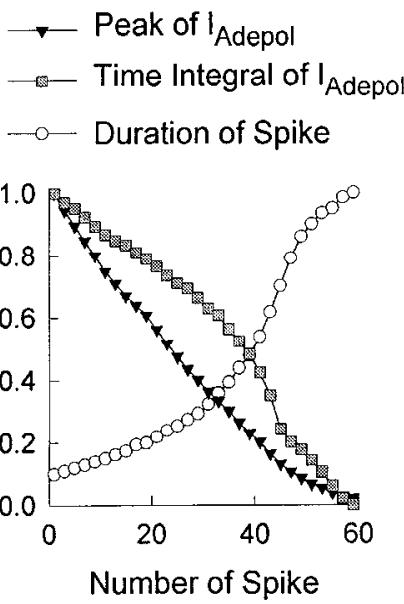

Figure 7. Inactivation of $I_{\text {Adepol }}$ parallels frequency-dependent spike broadening. $A$, An action potential train $(7 \mathrm{~Hz}, 9 \mathrm{sec})$ was evoked by injecting brief depolarizing current pulses into an R20 cell in normal ASW. $B, I_{\text {Adepol }}$ was determined by measuring difference currents obtained following addition of $1 \mathrm{mM} 4-\mathrm{AP}$, after $I_{\mathrm{K}-\mathrm{v}}$ and $I_{\mathrm{K}-\mathrm{Ca}}$ had been blocked by $40 \mathrm{mM}$ TEA. $C$, Peaks of $I_{\text {Adcpoi }}$, time integrals of $I_{\text {Adepol }}$, and durations of spikes, normalized to their maximum values, are plotted against spike number. The holding potential was $-40 \mathrm{mV}$.

to cumulative inactivation of the channels that carry the current, two other possible explanations must be considered.

One possibility is that the apparent cumulative inactivation of $I_{\text {Adepol }}$ was actually due to voltage- and state-dependent interactions between 4-AP and the channel (Hermann and Gorman, 1981a; Yao and Tseng, 1994). If 4-AP block were to be gradually reduced by a series of depolarizing voltage clamp pulses, the outward 4-AP difference current would decrease, as we observed in Figure 7, even with no cumulative $I_{\text {Adepol }}$ inactivation. This hypothesis was tested by measuring the inactivation of $I_{\mathrm{A}}$. depol with no 4-AP present. The other voltage-gated channels were first blocked, leaving $I_{\text {Adepol }}$ as the only time-dependent current. Under these conditions, the pattern of cumulative inactivation of $I_{\text {Adepol }}$ was the same as that measured using 4-AP difference currents. Moreover, with all voltage-gated channels blocked, repeated high frequency depolarizing pulses generated only leakage and capacitive currents, with no sign of activity-dependent relief of 4-AP (or TEA) block.

A second possible explanation for the decrease in $I_{\text {Adepol }}$ during the spike train is the gradual build-up of $\mathrm{K}^{+}$in a restrictcd cxtramembranous space, leading to a decreased driving force for $\mathrm{K}^{+}$currents (Eaton, 1972). This type of effect seems unlikely to play a major role, when one considers the gradual increases in $I_{\mathrm{K}-\mathrm{v}}$ and $I_{\mathrm{K}-\mathrm{Ca}}$ that occur in parallel with the decrease in $I_{\text {Adepol }}$ (cf. Figs. 7-9). These data are consistent with the hypothesis that the major cause of decay of $I_{\text {Adepol }}$ is cumulative channel inactivation.

$I_{\text {Adepol }}$ is the largest of the three voltage-gated outward currents that flow in the R20 cells during non-broadened spikes, which are accompanied by peaks of $I_{\text {Adepol }}$ ranging from $50 \mathrm{nA}$ to 110 $\mathrm{nA}(n=13)$, peaks of $I_{\mathrm{K}-\mathrm{V}}$ from 5 to $13 \mathrm{n} \Lambda(n=10)$, and peaks of $I_{\mathrm{K}-\mathrm{Ca}}$ from 4 to $10 \mathrm{nA}(n=7)$ (see also Fig. 12). The results described below suggest that the cumulative inactivation of $I_{\text {Adcpol }}$ is essential for spike broadening to occur.
A

Action Potential Train

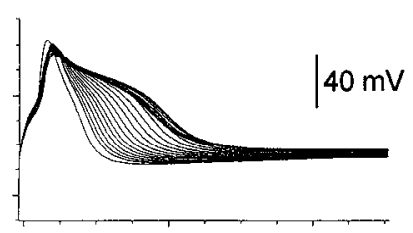

B

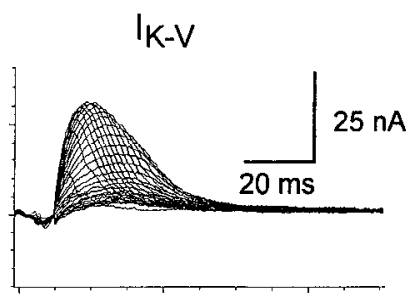

C
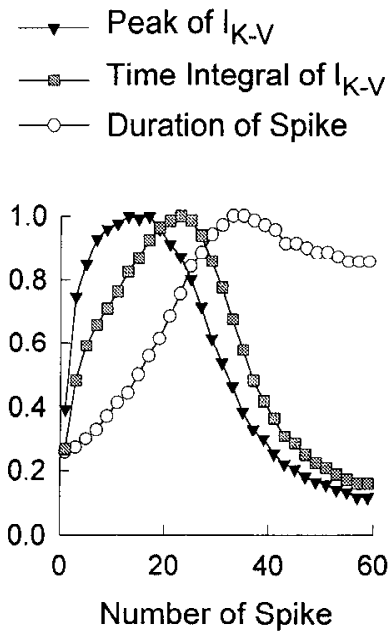

Figure 8. $I_{\mathrm{K}-\mathrm{v}}$ first increases and then decreases during a train of broadening spikes. $A$, An action potential train $(8 \mathrm{~Hz}, 8 \mathrm{sec}$ ) was evoked by injecting brief depolarizing current pulses into an R20 cell in normal ASW. $B$, Difference currents corresponding to $I_{\mathrm{K}-\mathrm{v}}$ were obtained by adding $40 \mathrm{mM}$ TEA, after $2 \mathrm{mM} \mathrm{CdCl}{ }_{2}$ had blocked $I_{\mathrm{Ca}}$ and $I_{\mathrm{K}-\mathrm{Ca}}$, and $60 \mu \mathrm{M}$ TTX had blocked $I_{\mathrm{Na}}$. C, Peaks of $I_{\mathrm{K}-\mathrm{v}}$, time integrals of $I_{\mathrm{K}-\mathrm{v}}$, and durations of spikes, normalized to their maximum values, are plotted against spike number. The holding potential was $-45 \mathrm{mV}$.

\section{$\mathrm{I}_{K-V}$ first increases and then decreases during spike broadening}

The contribution of $I_{\mathrm{K}-\mathrm{v}}$ to the action potentials in a train was determined by adding $40 \mathrm{mM}$ TEA after $I_{\mathrm{K}-\mathrm{Ca}}$ had been blocked by $2 \mathrm{mM} \mathrm{CdCl}_{2}$. The resultant TEA difference currents revealed the varying contributions of $I_{\mathrm{K}-\mathrm{V}}$ to individual spikes in the train (Fig. 8). $I_{\mathrm{K}-\mathrm{v}}$ during the first spike was relatively small, because of the slow activation kinetics of $I_{\mathrm{K}-\mathrm{v}}$. But as action potentials increased in duration, $I_{\mathrm{K}-\mathrm{V}}$ activated more completely. So the

A

Action Potential Train

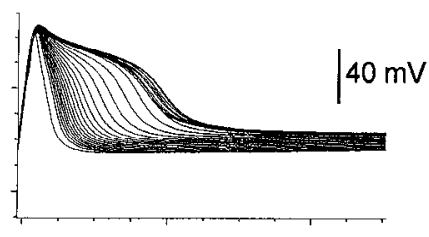

B

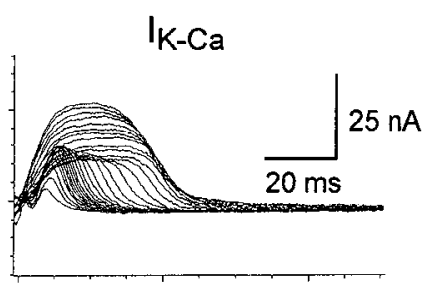

C
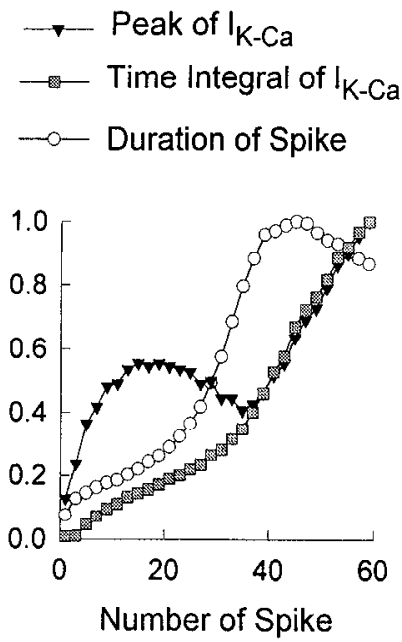

Figure 9. $I_{\mathrm{k} . \mathrm{Ca}}$ increases throughout a train of broadening spikes. $A$, An action potential train $(8 \mathrm{~Hz}, 8 \mathrm{sec})$ was evoked by injecting brief depolarizing current pulses into an R20 cell in normal ASW. B, BAPTA difference currents corresponding to $I_{\mathrm{K}-\mathrm{Ca}}$ were obtained hy iontophoresing BAPTA intracellularly through a third electrode ( $-30 \mathrm{nA}, 10 \mathrm{~min})$. $C$, Peaks of $I_{\mathrm{K}-\mathrm{Ca}}$, time integrals of $I_{\mathrm{K}-\mathrm{Ca}}$, and durations of spikes, normalized to their maximum values, are plotted against spike number. The holding potential was $-50 \mathrm{mV}$. 


\section{A}

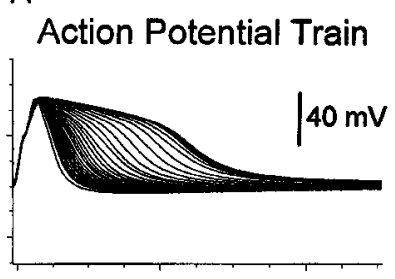

B

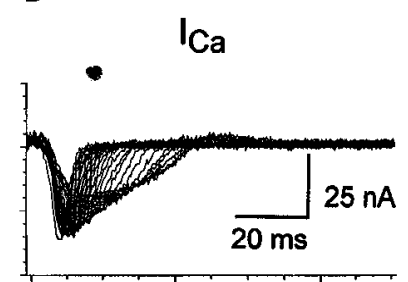

C
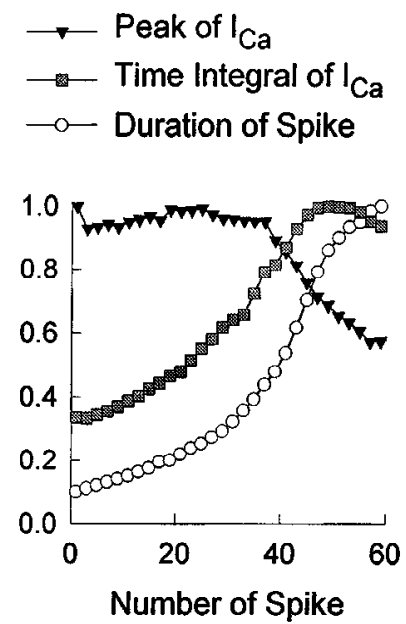

Figure 10. The time integral of $\mathrm{Ca}^{2+}$ current $\left(I_{\mathrm{Ca}}\right)$ increases during a train of broadening spikes. $A$, An action potential train $(7 \mathrm{~Hz}, 9 \mathrm{sec})$ was evoked by injecting brief depolarizing current pulses into an R20 cell in normal ASW. $B, \mathrm{Cd}^{2+}$ difference currents $\left(I_{\mathrm{Ca}}\right)$ were obtained by adding $2 \mathrm{mM} \mathrm{CdCl}_{2}$, after $40 \mathrm{mM}$ TEA, $1 \mathrm{mM} 4-\mathrm{AP}$, and $60 \mu \mathrm{M}$ TTX had blocked $\mathrm{K}^{+}$and $\mathrm{Na}^{+}$currents. $C$, Peaks of $I_{\mathrm{Ca}}$, time integrals of $I_{\mathrm{Ca}}$, and durations of spikes, normalized to their maximum values, are plotted against spike number. The holding potential was $-40 \mathrm{mV}$.

peaks and the time integrals of $I_{\mathrm{K}-\mathrm{v}}$ increased gradually from spike to spike and resisted spike broadening at the beginning of the spike train. Then the peaks began to decrease after about 20 spikes, due to slow, cumulative inactivation. When a $2 \mathrm{sec}$ step was given to $+40 \mathrm{mV}$ in voltage-clamp mode, we observed inactivation of $I_{\mathrm{K}-\mathrm{v}}$ with a time constant of about $1.2 \mathrm{sec}$ (data not shown). Gradual build-up of this slow inactivation presumably contributed to spike broadening during the latter part of the spike train. In addition, preliminary experiments indicate that brief depolarizing steps are more effective in inactivating $I_{\mathrm{K}-\mathrm{v}}$ than is a long step of duration equivalent to that of the sum of the short steps. A similar phenomenon, attributed to state-dependent inactivation, has been described previously for delayed rectifier currents in the mollusc Dorid (Aldrich, 1981) and in $\mathrm{K}^{+}$channels whose genes were cloned from rat brains (Marom and Levitan, 1994).

\section{$\mathrm{I}_{K-C_{a}}$ increases in two phases during spike broadening}

The contribution of $I_{\mathrm{K} \mathrm{Ca}}$ to spike broadening was determined by iontophoresing BAPTA into the cell. The resulting BAPTA difference current was small during the nonbroadened spikes and its peak and time integral increased, except for a transient dip in the peak, throughout the spike train (Fig. 9). The gradual increase in $I_{\mathrm{K}-\mathrm{Ca}_{\mathrm{a}}}$ quite likely is a major factor causing the duration of spikes to decrease after reaching their maximum value late in the train (see also Fig. 1). It may also contribute to the decrease in maximum spike broadening observed at higher spike frequencies (Fig. 1).

A possible explanation for the apparent increase in $I_{\mathrm{K}-\mathrm{Ca}}$ throughout the spike train is that injection of BAPTA, by decreasing the build-up of $\left[\mathrm{Ca}^{2+}\right]_{i}$, reduces $\mathrm{Ca}^{2+}$-dependent inactivation of $I_{\mathrm{Ca}}$ during the train (Eckert and Tillotson, 1981). In that case, the apparent increase in outward difference current attributed to facilitation of $I_{\mathrm{K}-\mathrm{Ca}}$ pre-BAPTA could actually be caused by an increase in $I_{\mathrm{Ca}}$ post-BAPTA. Three lines of evidence argue against such a possibility. First, the inactivation rate

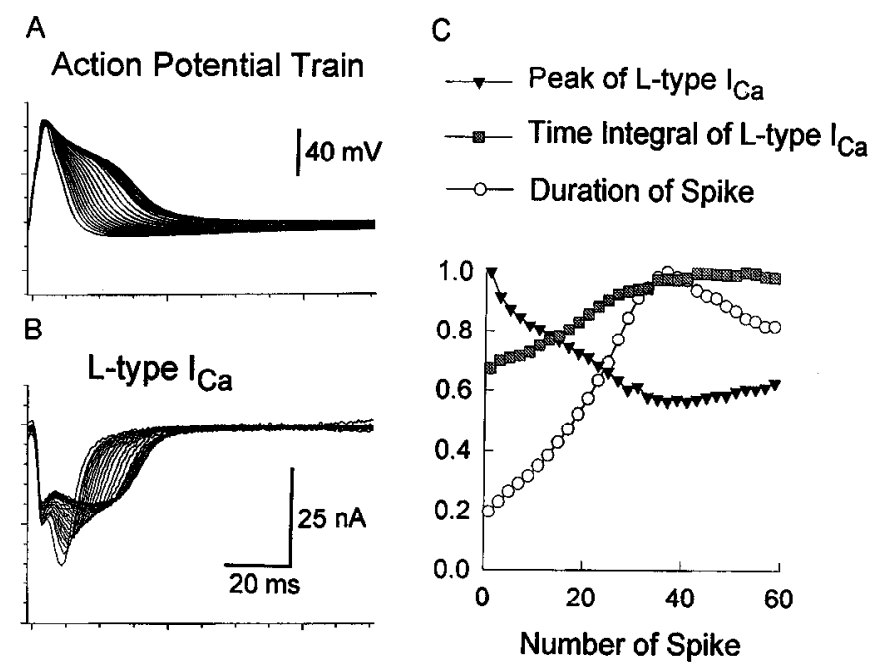

Figure 11. L-Type $I_{\mathrm{Ca}}$ does not facilitate during a train of broadening spikes. $A$, An action potential train $(8 \mathrm{~Hz}, 8 \mathrm{sec})$ was evoked by injecting brief depolarizing current pulses into an R20 cell in normal ASW. $B$, Nifedipine difference currents, corresponding to L-type $I_{\mathrm{Ca}}$, were obtained by addition of $10 \mu \mathrm{M}$ nifedipine, after $80 \mathrm{mM}$ TEA and 2 mM 4-AP had blocked most of the $\mathrm{K}^{+}$currents. $C$, Peaks of L-type $\mathrm{Ca}^{2+}$ currents, time integrals of L-type $\mathrm{Ca}^{2+}$ currents, and durations of spikes, normalized to their maximum values, are plotted against spike number. The holding potential was $-45 \mathrm{mV}$.

of current through the $\mathrm{Ca}^{2+}$ channels in the $\mathrm{R} 20$ cells did not increase when $\mathrm{Ca}^{2+}$ instead of $\mathrm{Ba}^{2+}$ was used as the current carrier. Second, applying a low dose of TEA ( $3 \mathrm{mM})$, which blocks more than $80 \%$ of $I_{\mathrm{K}-\mathrm{Ca}}$ in R20 cells without affecting other currents signiticantly, resulted in a difference current that exhibited facilitation during a train of broadening spikes similar to that observed for the BAPTA difference currents (data not shown). Third, after $I_{\mathrm{K}-\mathrm{Ca}}$ had been blocked by $40 \mathrm{mM}$ TEA, BAPTA injection did not cause an increase in inward current flow in response to a spike train command in voltage-clamp mode. These results are consistent with the conclusion that BAPTA difference currents accurately represent $I_{\mathrm{K}-\mathrm{ca}}$.

\section{$I_{C a}$ is prolonged during spike broadening}

$I_{\mathrm{Ca}}$ was monitored during the action potential train by adding 2 $\mathrm{mM} \mathrm{CdCl}{ }_{2}$ to obtain $\mathrm{Cd}^{2+}$ difference currents, after first blocking $I_{\mathrm{K}-\mathrm{Ca}}$ and $I_{\mathrm{K}-\mathrm{v}}$ with TEA, $I_{\text {Adepol }}$ with 4-AP, and $I_{\mathrm{Na}}$ with TTX. In some experiments, the peaks of $I_{\mathrm{Ca}}$ increased slightly as spike width increased early in the train. In other preparations, $I_{\mathrm{Ca}}$ was relatively constant at the beginning of the train (Fig. 10). These variations most likely arose from minor differences in shape of the early part of the spike. Later in the train, $I_{\mathrm{Ca}}$ decreased by about $30-40 \%$ of its peak value during the train (Fig. 10). This progressive decrement of $I_{\mathrm{Ca}}$ may be due to two factors: the cumulative inactivation of $\mathrm{Ca}^{2+}$ channels and the decreased driving forces caused by the prolonged falling phases of successive spikes. Since the peaks of $I_{\mathrm{Ca}}$ occurred a bit later than the peaks of action potentials, the broadened spikes tended to provide less driving force than the nonbroadened ones at the time when peak $I_{\mathrm{Ca}}$ occurs. This interpretation is supported by the fact that in cases where the spike shape resulted in a double peak of $I_{\mathrm{Ca}_{\mathrm{a}}}$ (e.g., Fig. 11), the decrease in $I_{\mathrm{Ca}}$ from spike-to-spike was greater for the second peak, which corresponds to the region of greater variability in membrane potential.

The waveform of $I_{\mathrm{Ca}}$ was somewhat variable, as it was quite 


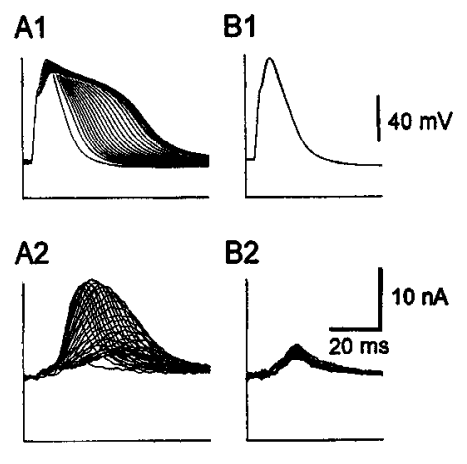

C

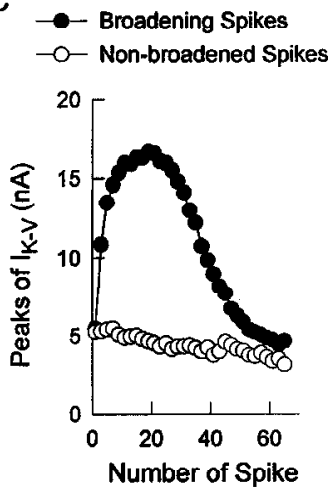

a. Control

b. IK-Ca and IK-V Blocked

c. IK-Ca, IK-V and IAdepol Blocked

d. IK-Ca, IK-V, IAdepol and ICa Blocked

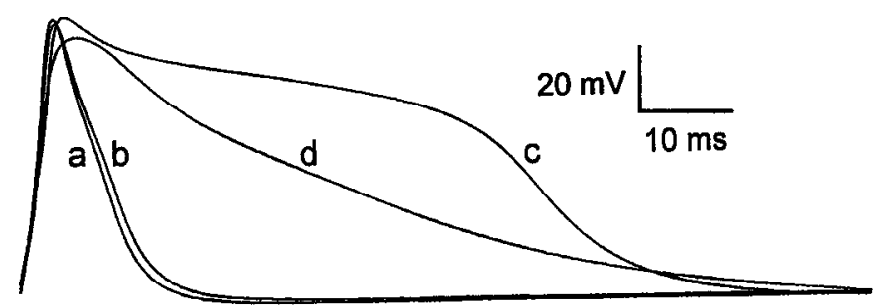

Figure 13. $I_{\text {Adepol }}$ is the most important outward current for determining the rate of repolarization for isolated action potentials in R20 cells. Action potentials were evoked by injecting brief depolarizing current pulses into the same R20 cell in: $a$, normal ASW; $b$, after blocking $I_{\text {K.y }}$ and $I_{\mathrm{K}-\mathrm{Ca}}$ with $70 \mathrm{mM}$ TEA; $c$, after blocking $I_{\text {Adepol }}$ with $1 \mathrm{mM} \mathrm{4-AP;} d$, after blocking $I_{\mathrm{Ca}}$ with $2 \mathrm{mM} \mathrm{CdCl}$. The various blocking drugs were added sequentially to the bath. The resting potential was $-50 \mathrm{mV}$. These data are representative of results from seven experiments.

during the broadened spikes late in the train than during the early spikes in the train (Fig. 10C). The increased duration of $I_{\mathrm{Ca}}$ was shown in current-clamp experiments to be essential for maintaining the shoulder of the broadened spike (Fig. 13).

Because $\mathrm{Ca}^{2+}$ currents through dihydropyridine-sensitive L-type channels in other preparations had been shown to facilitate with repeated depolarizations (Tiaho et al., 1994), we tested whether facilitation of L-type $\mathrm{Ca}^{2+}$ channels contributes to frequency-dependent spike broadening in the R20 cells (Fig. 11). The L-type $\mathrm{Ca}^{2+}$ currents that flow during a spike train were obtained by measuring difference currents resulting from application of $10 \mu \mathrm{M}$ nifedipine (Edmonds et al., 1990). Outward currents were preblocked to avoid possible nonspecific effects of nifedipine (Ncrbonne and Gurney, 1987). The time courses of L-type $I_{\mathrm{Ca}}$ also varied among different preparations, like total $I_{\mathrm{Ca}}$. In some cases they had two peaks (Fig. 11), but in others they had only one. Regardless of their precise waveforms, the peaks of L-type $I_{\mathrm{Ca}}$ gradually inactivated and the time integrals of L-type $I_{\mathrm{Ca}}$ increased by an average of $103 \%( \pm 27 \%, N=3)$ during a spike train. This increase in $\mathrm{Ca}^{2+}$ influx through L-type $\mathrm{Ca}^{2+}$ channels appears not to result from a facilitation of L-lype $I_{\mathrm{Ca}}$ amplitude, but rather from the prolongation of its time course.

\section{Preventing spike broadening selectively blocks the activity-} dependent changes in various ionic currents

The results described above suggest a basic dichotomy in the contributions of different types of ionic currents to spike broadening. The parallel between the monotonic increase in inactivation of $I_{\text {Adepol }}$ and the increase in spike broadening throughout a train (Fig. 7) suggests that the cumulative inactivation of $I_{\text {Adepol }}$ may be the primary cause of broadening. In contrast, the amplitudes of the other currents vary either very little from spiketo-spike, or vary in ways that cannot explain the main trend in spike widths. We hypothesize that the major changes in currents other than $I_{\text {Adepol }}$ result secondarily from the gradually increasing spike width caused by inactivation of $I_{\text {Adepot }}$. To test this hypothesis, we determined the activity-dependent changes of various currents during trains of nonbroadened spikes generated in voltage clamp mode (Fig. 12). $I_{\mathrm{K} . \mathrm{v}}$, which increased early in a train

of broadening spikes and decreased later in the train (Figs. 8, sensitive to the shape of the rising phase of the action potential. Thus, in some cases $I_{\mathrm{Ca}}$ had two peaks, one on the rising and one on the falling phase of the spike (cf. Fig. 11). The notch between peaks has been attributed to a transient decrease in driving force as the spike nears its peak (Crest and Gola, 1993) Regardless of the precise shapes of the $I_{\mathrm{Ca}}$ traces, their time integrals increased on the average by $203 \%$ during the train $( \pm 31 \%, N=8)$, indicating that more $\mathrm{Ca}^{2+}$ flowed into the cell 
$12 A, C)$, exhibited only gradual inactivation during a train of nonbroadened spikes (Fig. $12 B-D$ ). $I_{\mathrm{K}-\mathrm{Ca}}$, which facilitated throughout most of the train of broadening spikes (Fig. 9), did not change significantly during a train of nombroadened spikes (Fig. 12D). Among the three major $\mathrm{K}^{+}$currents in R20 cells, only $I_{\text {Adcpol }}$ changed during a train of nonbroadened spikes similar to the way in which it changed when broadening was allowed to occur. However, the final level of cumulative inactivation of $I_{\text {Adepol }}$ during the train of nonbroadened spikes was not as complete as that during a train of broadening spikes, indicating that the broadened spikes enhance the degree of cumulative inactivation of this current (cf. Figs. 7, 12D). $I_{\mathrm{Na}}$, which is virtually completely terminated by the end of the first spike in the train, was unaffected by the lack of broadening (cf. Figs. 6, 12D). $I_{\mathrm{Ca}}$, which normally decreased in amplitude late in the train, showed little or no change in amplitude when broadening was prevented (cf. Figs. 10, 12D). The time integrals of the individual $\mathrm{Ca}^{2+}$ currents also did not change (data not shown), since the constancy of the spike durations prevented the $\mathrm{Ca}^{2+}$ channel open times from increasing. These results support the hypothesis that the cumulative inactivation of $I_{\text {Adepol }}$ is the driving force for spike broadening, and that the major changes of the other currents during a train are caused by the resultant increases in spike width.

\section{Current-clamp data support conclusions from voltage-clamp experiments}

Based on the voltage-clamp data described above, from experiments in which spike waveforms were used for the clamp command, we propose the following hypothesis for the mechanism of spike broadening in the R20 cells. $I_{\text {Adepol }}$ is the largest outward current in the nonbroadened spikes, and its cumulative inactivation is the key factor leading to spike broadening (Fig. 7). The increasing spike widths in turn lead to pronounced changes in $I_{\mathrm{K}-\mathrm{V}}$ and $I_{\mathrm{K}-\mathrm{Ca}}$. Because they are activated relatively slowly, $I_{\mathrm{K}-\mathrm{v}}$ and $I_{\mathrm{K}-\mathrm{Ca}}$ play minor roles in determining spike width for normal duration spikes. But as the train progresses, their amplitudes and durations begin to increase, secondary to changes in spike duration caused by the decrease in $I_{\text {Adepol }}$. The biphasic changes in $I_{\mathrm{K}-\mathrm{v}}$ affect the kinetics of spike broadening by resisting broadening in the beginning and contributing to it later in the spike train (Fig. 8). The gradual increase in $I_{\mathrm{K}-\mathrm{Ca}}$ works against spike broadening throughout the train, and limits the ultimate extent of broadening (Fig. 9). The prolonged $I_{\mathrm{Ca}}$ waveforms during later spikes in the train maintain the shoulders of the broadened action potentials, but the gradual cumulative inactivation of $I_{\mathrm{Ca}}$ may contribute to limiting the maximum extent of broadening.

We tested these proposed roles of $I_{\mathrm{Adepoi}}, I_{\mathrm{K}-\mathrm{V}}, I_{\mathrm{K}-\mathrm{Ca}}$, and $I_{\mathrm{Ca}}$ by doing two experiments under current clamp. In the first experiment, we blocked each of these currents in this order: $I_{\mathrm{K}-\mathrm{v}}$ and $I_{\mathrm{K} \text {-Ca}}, I_{\text {Adepol }}$, and $I_{\mathrm{Ca}}$. A single action potential was recorded in normal ASW, after which $70 \mathrm{~mm}$ TEA, $1 \mathrm{~mm} \mathrm{4-AP,} \mathrm{and} 2 \mathrm{~mm}$ $\mathrm{CdCl}_{2}$ were added sequentially to the bath. The action potential recorded under each of the four conditions is shown in Figure 13. Trace (a) is the control spike recorded with the ganglion bathed in ASW. Application of $70 \mathrm{mM}$ TEA, which blocks both $I_{\mathrm{K}-\mathrm{Ca}}$ and $I_{\mathrm{K}-\mathrm{v}}$, had virtually no effect on spike shape (b). Blocking $I_{\text {Adepol }}$ with $1 \mathrm{mM} 4-\mathrm{AP}$ caused the spike to widen severalfold (c). After $\mathrm{Ca}^{2+}$ currents were blocked by $\mathrm{CdCl}_{2}$, the membrane potential repolarized passively after reaching its peak (d). These results confirm the hypothesis that $I_{\text {Adepol }}$ is the most important of the various outward currents for controlling R20 spike dura- tion when the resting cell is stimulated, and that $I_{\mathrm{Ca}}$ is essential for maximal prolongation of the broadened spike.

In the second test of the hypothesized roles of the different currents under current clamp, $I_{\mathrm{K}-\mathrm{Ca}}$ and $I_{\mathrm{K}-\mathrm{v}}$ were blocked sequentially. $I_{\mathrm{K}-\mathrm{Ca}}$ was blocked first, by iontophoresing either EGTA or BAPTA into the cell (Fig. 14A2). The first spike in a $5 \mathrm{~Hz}, 10 \mathrm{sec}$ train was unaffected by blocking $I_{\mathrm{K}-\mathrm{Ca}}$ (cf. Fig. $14 A 1, A 2)$, but the two curves plotting spike width versus spike number, measured either in control conditions or with $I_{\mathrm{K}-\mathrm{Ca}}$ blocked, diverge increasingly as spike number is increased (Fig. $14 B I$ ). With $I_{\mathrm{K}-\mathrm{Ca}}$ blocked the maximum increase in spike width resulted in a 6.6-fold broadening (Fig. 14A2), compared to 4.0fold broadening in the control (Fig. 14AI). The slopes of the two corresponding normalized curves diverge only late in the train (Fig. 14B2), where $I_{\mathrm{K}-\mathrm{Ca}}$ increases especially steeply as a function of spike number when the cell is under voltage-clamp control (Fig. 9). Note that both curves, as well as the two corresponding un-normalized curves (Fig. 14BI), have a region of concavity in the middle of each train, in the range where $I_{\mathrm{K}-\mathrm{V}}$ was found to increase in the voltage-clamp experiments (Fig. 8). Subsequent addition of $50 \mathrm{mM}$ TEA to the bath, to block $I_{\mathrm{K}-\mathrm{v}}$, accelerated the rate of broadening in this region, causing the final set of curves to be convex $\left(\mathrm{I}_{\mathrm{K}-\mathrm{Ca}}\right.$ and $I_{\mathrm{K}-\mathrm{V}}$ blocked, Fig. $14 B 1, B 2$ ). However, blocking $I_{\mathrm{K}-\mathrm{v}}$ had a relatively small incremental effect on the final extent of broadening measured at the end of the spike train (7.0-fold broadening in Fig. 14A.3; cf. 6.6fold broadening in Fig. 14A2). This observation is consistent with the fact that $I_{\mathrm{K}-\mathrm{v}}$ is largely inactivated at the end of a spike train in voltage-clamp mode (Fig. $8 C$ ). These results provide further support for the hypothesis that $I_{\mathrm{K}-\mathrm{v}}$ affects mainly the temporal pattern of broadening, whereas $I_{\mathrm{K}-\mathrm{Ca}}$ affects both the rate and maximum extent of broadening. Computer simulation of the electrical properties of the R20 cells will be required to test these conclusions quantitatively.

\section{Expression of $\mathrm{I}_{\text {Adepol }}$ does not necessarily result in spike broadening}

Although the expression of $I_{\text {Adcpo }}$ channels in a cell can play a critical role in causing spike broadening, one cannot generalize this result to say that any given neuron with a significant component of $I_{\text {Adepol }}$ will undergo significant frequency-dependent spike broadening. Rather, it is the entire complement of channel types expressed in the cell that determines whether such bruadening occurs. For example, cell R15 and the RB cells of Aplysia, both of which generate significant levels of $I_{\text {Adepol }}$ (Furukawa et al., 1992 and our unpublished observations), exhibit only minor frequency-dependent spike broadening (Fig. 15). Meech (1974) had found that following EGTA injection into R15 to block $I_{\mathrm{K}-\mathrm{Ca}}$, the train of spikes elicited by a steady depolarizing current gradually transforms into a several-second long plateau potential. We tested the role of $I_{\mathrm{K}-\mathrm{Ca}}$ in spike repolarization in both $\mathrm{R} 15$ and the $\mathrm{RB}$ cells by recording $4 \mathrm{~Hz}$ action potential trains before and after iontophoresing EGTA into their somata. Before introducing EGTA, maximum spike broadening was 1.5-fold in $\mathrm{R} 15$ and 1.3-fold in an RB cell during a $4 \mathrm{~Hz}, 5 \mathrm{sec}$ spike train (Fig. 15AI,BI). After blocking $I_{\mathrm{K}-\mathrm{Ca}}$ in R15, the first spike broadened 2.2 fold ( $\pm 0.2, N=4)$ and subsequent spikes in the train broadened more than fivefold $(N=4)$ (Fig. 15A2). Thus, $I_{\mathrm{K}-\mathrm{Ca}}$ plays a major role in repolarization in $\mathrm{R} 15$, even during a single action potential. $I_{\mathrm{K}-\mathrm{Ca}}$ is even more important for spike repolarization in single spikes in the RB cells. Blocking $I_{\mathrm{K}-\mathrm{Ca}}$ in the RB cell caused the first spike in the train to broaden by 3.0 -fold 
A1

\section{Control}

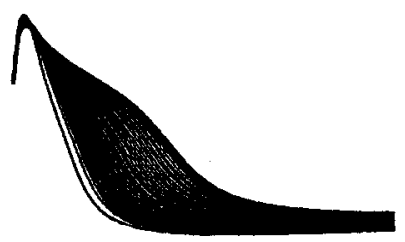

A2
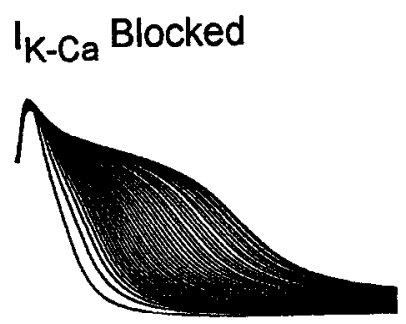

A3
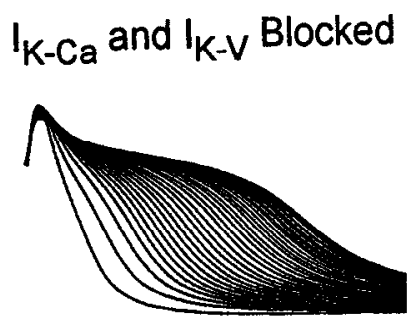

$20 \mathrm{~ms}$
B1

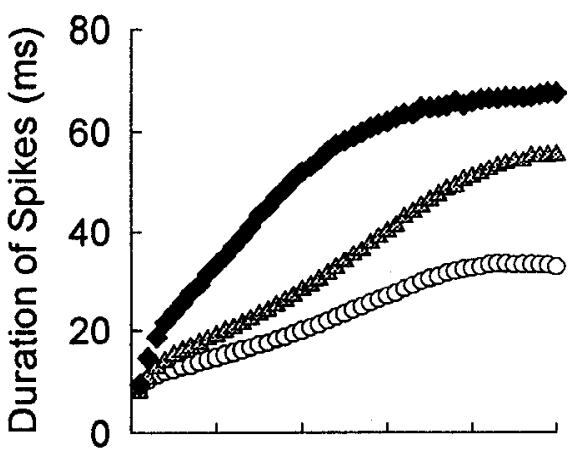

\section{B2}

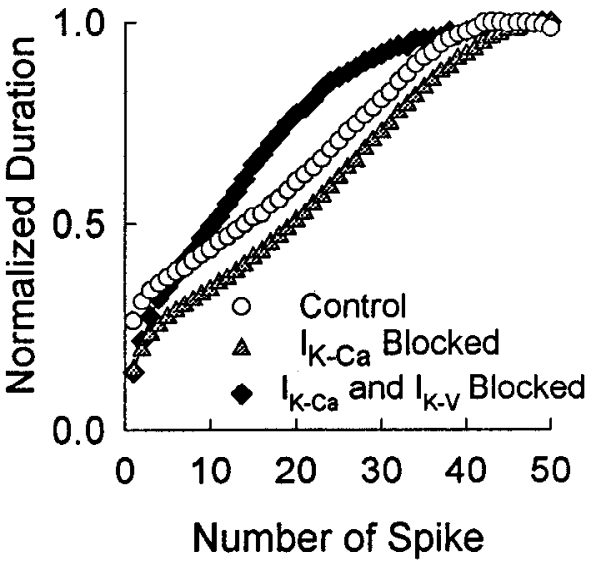

Figure 14. Blocking $I_{\mathrm{K} \text {-Ca }}$ increases both the rate and extent of spike broadening, while blocking $I_{\mathrm{K}-\mathrm{v}}$ increases primarily the rate of broadening in $\mathrm{R} 20$ cells. $A$, Action potential trains $(5 \mathrm{~Hz}$, $10 \mathrm{sec}$ ) were evoked by injecting brief depolarizing current pulses into the soma of an R20 cell: $A 1$, in normal ASW; $A 2$, after blocking $I_{\mathrm{K}-\mathrm{Ca}_{\mathrm{a}}}$ by iontophoresing EGTA intracellularly $(-30$ $\mathrm{nA}, 10 \mathrm{~min}) ; A 3$, after blocking $I_{\mathrm{K}-\mathrm{v}}$ with $50 \mathrm{mM}$ TEA. The resting potential was $-50 \mathrm{mV}(N=3)$. B1, Durations of spikes under the three conditions in $A$ are plotted against spike number. $B 2$, Durations of spikes, normalized to their maximum value during each train, are plotted against spike number.
$( \pm 0.2, N=3$ ) (Fig. 15B2). The last spike in a train broadened by 2.2 -fold ( $\pm 0.2, N=3$ ), compared to the first spike after injection of EGTA (Fig. 15B). The kinetics of broadening in $\mathrm{R} 15$ and RB cells in which $I_{\mathrm{K}-\mathrm{Ca}}$ had been blocked is presumably determined primarily by the rate of cumulative inactivation of $I_{\text {Adepol }}$ and of delayed rectifier currents (Hermann and Gorman, $1981 \mathrm{a}, \mathrm{b})$. These results demonstrate that the expression of $I_{\text {Adepol }}$ in a neuron does not in itself allow one to predict the extent of frequency-dependent spike broadening.

\section{Discussion}

Functional significance of spike broadening in the $R 20$ cells We found that the electrotonic EPSPs from one R20 cell to another facilitated twofold in amplitude and fourfold in area during a train of gradually broadening action potentials (Fig. 4). Such activity-dependent facilitation of electrical transmission is generally thought to result from the low-pass filtering properties of the electrotonic junction in series with the postsynaptic membranc (Bennett, 1966), together with frequency-dependent spike broadening in the presynaptic cell (Berry, 1972; Carew and Kandel, 19.77). Our results support this hypothesis by directly demonstrating the importance of increased spike duration in generating activity-dependent facilitation at electrical synapses.

Frequency-dependent spike broadening was also found to enhance chemical synaptic transmission by the R20 cells. There are two likely mechanisms by which spike broadening during a train could increase the effectiveness of synaptic transmission. First, it may increase terminal invasion. There may be a region of low safety margin for conduction, at or near the terminal arborization of the R20 axon in the abdominal ganglion, as described in Helix (Pin et al., 1994). If this is the case for R20, frequency-depcndent spikc broadening may increase the probability of spike invasion into the terminals, similar to the way in which low temperature-induced spike broadening enhances conduction in squid axons at branch points where impedance mismatches exist (Westerfield et al., 1978). The mechanism by which such spike broadening might enhance terminal invasion has been demonstrated in a computational model (Laascher and Shiner, 1990). Activity dependent enhancement of terminal invasion has also been described empirically in a variety of preparations (Bennett, 1972), including neuron C2 of $A$. californica and the neuroendocrine bag cells of $A$. brasiliana (Dudek and Blankenship, 1976; Weiss et al., 1986). The latter example is particularly relevant, because the homologous cells in A. californica undergo pronounced frequency-dependent spike broadening (Quattrocki et al., 1994).

A second way in which spike broadening might enhance release is to cause an increase in intraterminal levels of $\left[\mathrm{Ca}^{2+}\right]_{i}$ by increasing $\mathrm{Ca}^{2+}$ channel open time. We did not measure $\left[\mathrm{Ca}^{2+}\right]_{i}$, but did measure $I_{\mathrm{Ca}}$ across the soma membrane. Although the peaks of $I_{\mathrm{Ca}}$ decreased slightly during a train, the time integrals of $I_{\mathrm{Ca}}$ increased, as the broadened spikes allowed $\mathrm{Ca}^{2+}$ channels to stay open longer. Our data may underestimate the effects of spike broadening on $I_{\mathrm{Ca}}$ involved in release, for three reasons. First, we did not have space-clamp control of the presynaptic terminals, which are some unknown electrotonic distance away from the cell bodies. Therefore, we did not measure the full $I_{\mathrm{Ca}}$ in the terminals of the R20 cell. Second, the fraction of measured 
R15

RB

A1

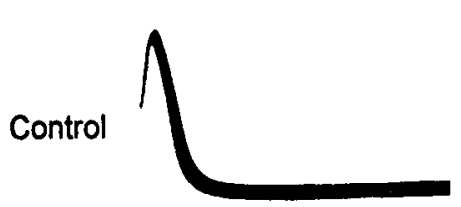

B1

A2

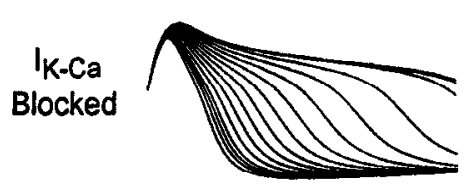

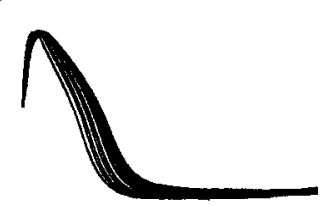

B2

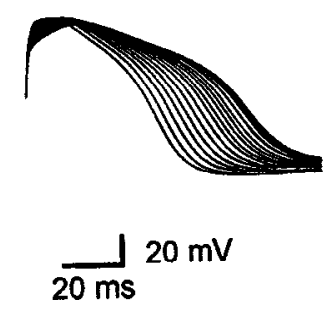

Figure 15. The presence of $I_{\text {Adepo }}$ in a cell does not in itself endow the cell with pronounced frequency-dependent broadening characteristics. Although both R15 and the RB cells generate significant $I_{\text {Adepol}}$, neither one exhibits major frequency-dependent broadening, in part because of the important role played by $I_{\mathrm{K}-\mathrm{Ca}_{\mathrm{a}}}$ in spike repolarization in these cells. $A$, Action potential trains were evoked by injecting brief depolarizing current pulses into the soma of an R15 cell: $A 1$, in normal ASW; $A 2$, after blocking $I_{\mathrm{K}-\mathrm{Ca}}$ by iontophoresing EGTA intracellularly $(-50 \mathrm{nA}, 20 \mathrm{~min}) .(N=4)$. $B$, Action potential trains were evoked by injecting brief depolarizing current pulses into the soma of an RB cell in: $B 1$, normal ASW; $B 2$, after blocking $I_{\mathrm{K}-\mathrm{Ca}}$ by injecting EGTA intracellularly $(-30 \mathrm{nA}, 20 \mathrm{~min})(N=3) ; 4 \mathrm{~Hz}, 5 \mathrm{sec}$ trains of spikes were used for both cells. (It was typically not possible to fire R15 and RB cells at frequencies higher than $4 \mathrm{~Hz}$ because of pronounced accommodation).

current that flows across the soma and proximal axon membrane will have no direct effect on release. Third, not all types of $I_{\mathrm{Ca}}$, even at the terminals, are necessarily involved in transmitter release (e.g., Eliot et al., 1993).

One factor supporting the hypothesis that the progressive increase in the time integrals of $I_{\mathrm{Ca}}$ throughout the train may be responsible for the facilitation of transmitter release is the fact that the R20 cells appear to be peptidergic (Alevizos et al,, 1989). Neuropeptide release is thought to be controlled not so much by local submembranous domains of $\left[\mathrm{Ca}^{2+}\right]_{i}$ as by the overall level of $\left[\mathrm{Ca}^{2+}\right]_{i}$ in the terminal boutons, which may effectively integrate the total $\mathrm{Ca}^{2+}$ influx over a relatively long time period. As a result, rclease by peptidergic neurons can facilitate, even in situations where peaks in $\left[\mathrm{Ca}^{2+}\right]_{i}$ are decreasing, so long as the time-averaged $\left[\mathrm{Ca}^{2+}\right]_{i}$ in the bulk cytoplasm is increasing (Verhage, et al., 1991; Peng and Zucker, 1993). Such may be the case for the R20 cells, assuming that the processes we observe in the soma are mirrored by events in the terminals. Further experiments will be required to determine the extent to which the effect of broadening on transmitter release is caused either by increased terminal invasion or by increased $\left[\mathrm{Ca}^{2+}\right]_{i}$ resulting from longer spike durations in the terminal.

What is the physiological role of spike broadening of R20 cells? Do they cver firc in the frequency range of $4-5 \mathrm{~Hz}$ required to produce maximum frequency-dependent spike broadening? This question is currently under investigation, by chronically recording from the R20 cells' axons in vivo.

\section{Mechanisms of spike broadening in the $R 20$ cells}

The membrane of an R20 cell contains a complex system of voltage-gated ion channels, several of which contribute to determining the frequency dependence of the waveform of the action potential. Three $\mathrm{K}^{+}$currents $\left(I_{\text {Adepol }}, I_{\mathrm{K}-\mathrm{v}}\right.$ and $\left.I_{\mathrm{K}-\mathrm{C}_{2}}\right)$, a multicomponent $I_{\mathrm{Ca}}$, and $I_{\mathrm{Na}}$ are generated by each R20 cell. The kinetics of $I_{\mathrm{K}-\mathrm{Ca}}$ activation suggest that it is made up of at least two separate components. Most of these different currents have also been found in other Aplysia neurons that do not exhibit pronounced frequency dependent broadening, consistent with the hypothesis that it is the unique mixture of current types in a given cell that determines the extent to which it expresses such broadening (Crest et al., 1990).

$I_{\text {Adepol }}$ plays an essential role in determining the extreme spike broadening observed in the R20 cells, for three reasons. First, it is the largest outward current that flows during an isolated spike in the R20 cells. Second, it is activated and inactivated at a relatively depolarized range of voltage (Furukawa et al., 1992), which means it is not inactivated at resting membrane potential, unlike the traditional A currents in Aplysia ( $I_{\text {Afast }}$ and $I_{\text {Aslow }}$ ). Third, it has two relatively slow time constants of recovery from inactivation ( $22 \mathrm{sec}$ and $0.5 \mathrm{sec}$; Furukawa et al., 1992) that may account for the pronounced cumulative inactivation observed at high spike frequencies (Fig. 7).

As the action potential broadens, due to the gradual inactivation of $I_{\text {Adepol }}, I_{\mathrm{Ca}}$ is prolonged, as the $\mathrm{Ca}^{2+}$ channels stay open longer. The resultant increase in $\mathrm{Ca}^{2+}$ influx is critical for maintaining the shoulder of the broadened action potential. But the gradual decrease in peak $I_{\mathrm{Ca}}$ from spike to spike, due to inactivation, plays a role in limiting the ultimate extent of hroadening in a train.

The other two outward currents, $I_{\mathrm{K}-\mathrm{v}}$ and $I_{\mathrm{K} \text {-Ca }}$, are effectively latent currents. For the first spike in the train, their amplitudes are so small that blocking them completely has no effect on spike width (Fig. 13, 14). But as the train continues, and as broadening progresses, they both emerge to temper the broadening caused by the decrease in $I_{\text {Adepol }}$ amplitude and the increase in $I_{\mathrm{Ca}}$ duration.

$I_{\mathrm{K}-\mathrm{v}}$ first increases, and then decreases during a spike train (Fig. 8). We hypothesize that this bimodal response can be explained by two competing processes-slow activation and cumulative inactivation. The first spike in the train is too brief to activate $I_{\mathrm{K}-\mathrm{v}}$ significantly. As the spikes become longer, the $I_{\mathrm{K}-\mathrm{V}}$ channels have a greater chance of opening before repolarization occurs. On the other hand, as the train continues, and as each spike in the train becomes longer, the fraction of channels entering the inactivated state increases. The current eventually approaches its initial value by the end of the train. Thus, changes in $I_{\mathrm{K}-\mathrm{V}}$ act as a brake on spike broadening early in the train and accelerate broadening late in the train.

$I_{\mathrm{K}-\mathrm{Ca}}$ increases during most of the train. This increase in outward current limits the maximum value of spike broadening, and may even cause a slight spike narrowing at the end of some high frequency trains (Figs. 1, 9, 14). The build-up of $I_{\mathrm{K}-\mathrm{Ca}}$ is presumably determined by three factors: (1) the slow activation of $I_{\mathrm{K}-\mathrm{Ca}}$ relative to spike duration, coupled with (2) the gradual increase in spike width during the train, plus (3) a gradual increasc in baseline $\left[\mathrm{Ca}^{2+}\right]_{i}$ during the spike train due to overloading of the cytoplasmic $\mathrm{Ca}^{2+}$ buffering system (Gorman and Thomas, 1980; Connor et al., 1986; Crest and Gola, 1993; Thompson, 1994). 
Comparison of mechanisms that underlie frequency-dependent spike broadening in various preparations

The mechanisms of frequency-dependent spike broadening have been investigated in both vertebrates and invertebrates. For each of the preparations used, depression of one or more types of $I_{\mathrm{K}}$ appears to be largely responsible for frequency-dependent spike broadening. Jackson et al. (1991) showed that cumulative inactivation of $I_{\mathrm{K}}$ is likely to be the major cause of frequency-dependent spike broadening in the pituitary nerve terminals in rats. Two candidate components of the inactivating current were then identified at the single channel level (Bielefeldt et al., 1992), including one that is $\mathrm{Ca}^{2+}$ sensitive. In isolated neuronal somata of Dorids, successive action potentials in a train grow in duration primarily as a result of the cumulative, state-dependent inactivation of a delayed rectifier current resembling $I_{\mathrm{K} \cdot \mathrm{v}}$ in the R20 cells (Aldrich et al., 1979). Current-clamp data suggest that a similar process may cause the frequency-dependent spike broadening observed in Pleuobranchaea (Gillette et al., 1982). In the $\mathrm{P}$ cells of Helix, both $I_{\mathrm{K}-\mathrm{V}}$ and $I_{\mathrm{K}-\mathrm{C} \text {-type channels are }}$ thought to inactivate during a spike train (Crest et al., 1990). As in the R20 cells, sustained $\mathrm{Ca}^{2+}$ influx has been found to be important for mediating frequency-dependent spike broadening in several other types of molluscan neurons (Aldrich et al., 1979; Edstrom and Lukowiak, 1985; Crest and Gola, 1993).

Frequency-dependent spike broadening in Aplysia has been studied most extensively in three types of neurons-the R20 cells, the sensory cells in the pleural ganglia (Edstrom and Lukowiak, 1985), and the neuroendocrine bag cells. The unusually large degree of broadening found in the R20 cells appears to result primarily from the fact that $I_{\text {Adepol }}$, which exhibits pronounced cumulative inactivation, is the major current responsible for spike repolarization in these cells. In the pleural sensory neurons, a different high threshold, rapidly activating $\mathrm{K}^{+}$current, $I_{\mathrm{K}, \mathrm{V}}$, is the current most important for spike repolarization (Baxter and Byrne, 1990). Given that it also recovers slowly from inactivation (Baxter and Byrne, 1989), $I_{\mathrm{K}, \mathrm{V}}$ seems a likely candidate to mediate frequency-dependent spike broadening in the sensory cells. Frequency-dependent spike broadening in the bag cells is caused by the cumulative inactivation of a third type of $\mathrm{K}^{+}$current, IK2, a slowly inactivating delayed rectifier current carried by the shab $\mathrm{K}^{+}$channels (Quattrocki et al., 1994). Thus, the emerging picture suggests that cumulative inactivation of voltage-gated $\mathrm{K}^{+}$channels is a common cause of spike broadening in a variety of preparations, and there exists a diverse set of $\mathrm{K}^{+}$channel types that can fill this role. In addition, the results from this study demonstrate that other outward currents can increase at various stages of a train of broadening spikes, thereby influencing the temporal pattern and ultimate extent of increasing spike width.

\section{References}

Aldrich RW (1981) Inactivation of voltage-gated delayed potassium current in molluscan neurons. A kinetic model. Biophys J 36:519532.

Aldrich RW, Getting PA, Thompson SH (1979) Mechanism of frequency-dependent broadening of molluscan neurone soma spikes. $\mathbf{J}$ Physiol (Lond) 291:531-544.

Alevizos A, Weiss KR, Koester J (1989) SCP-containing R20 neurons modulate respiratory pumping in Aplysia. J Neurosci 9:3058-3071.

Alevizos A, Weiss KR, Koester J (1991) Synaptic actions of identified peptidergic neuron R15 in Aplysia. I. Activation of respiratory pumping. J Neurosci 11:1263-1274.

Augustine GT (1990) Regulation of transmitter release at the squid giant synapse by presynaptic delayed rectifier potassium current. J Physiol (Lond) 431:343-364.

Baxter DA, Byrne JH (1989) Serotonergic modulation of two potassium currents in the pleural sensory neurons of Aplysia. J Neurophysiol 62:665-679.

Baxter DA, Byrne JH (1990) Reduction of voltage-activated $\mathrm{K}^{+}$currents by forskolin is not mediated via cAMP in pleural sensory neurons of Aplysia. J Neurophysiol 64:1474-1483.

Bennett MVL (1966) Physiology of electrotonic junctions. Ann NY Acad Sci 137:509-539.

Bennett MVL (1972) Comparison of electrically and chemically mediated synaptic transmission. In: Structure and function of synapses (Pappas GD, Purpura DP, eds), pp 221-256. New York: Raven.

Berry MS (1972) A system of electrically coupled small cells in the buccal ganglia of the pond snail Planorbis corneus. J Exp Biol 56: 621-637.

Bielefeldt K, Rotter JL, Jackson MB (1992) Three potassium channels in rat posterior pituitary nerve terminals. J Physiol (Lond) 458:4167.

Bourque CW (1991) Activity-dependent modulation of nerve terminal excitation in a mammalian peptidergic system. Trends Neurosci 14: 28-30.

Brezina V (1988) Acetylcholine suppresses calcium current in neurons of Aplysia californica. Comp Biochem Physiol 91:2219-2228.

Byrne J (1983) Identification and initial characterization of a cluster of command and pattern-generating neurons underlying respiratory pumping in Aplysia califormica. J Neurophysiol 49:491-508.

Carew TJ, Kandel ER (1977) Inking in Aplysia californica. II. Central program for inking. J Neurophysiol 40:708-720.

Clapham DE (1995) Calcium signaling. Cell 80:259-268.

Coates CJ, Bulloch AG (1985) Synaptic plasticity in the molluscan peripheral nervous system: physiology and role for peptides. J Neurosci 5:2677-2684.

Connor JA, Kretz R, Shapiro E (1986) Calcium levels measured in a presynaptic neurone of Aplysia under conditions that modulate transmitter release. J Physiol (Lond) 375:625-642.

Crest M, Gola M (1993) Large conductance $\mathrm{Ca}^{2+}$-activated $\mathrm{K}^{+}$channels are involved in both spike shaping and firing regulation in Helix neurons. J Physiol (Lond) 465:265-287.

Crest M, Watanabe K, Gola M (1990) Two subtypes of C current in identified Helix neurons. Brain Res 518:299-302.

Crest M, Jacquet G, Gola M, Zerrouk H, Benslimane A, Rochat $H$ Mansuelle P, Martin-Eauclaire M-F (1992) Kaliotoxin, a novel peptidyl inhibitor of neuronal BK-type $\mathrm{Ca}^{2+}$-activated $\mathrm{K}^{+}$channels characterized from Androctonus mauretanicus mauretanicus venom. J Biol Chem 267:1640-1647.

Deitmer JW, Eckert R (1985) Two components of Ca-dependent potassium current in identified neurons of Aplysia californica. Pfluegers Arch 403:353 359 .

Dudek FE, Blankenship JE (1976) Neuroendocrine (bag) cells of Aplysia: spike blockade and a mechanism for potentiation. Science 192: 1009-1010.

Eaton DC (1972) Potassium ion accumulation near a pace-making cell of Aplysia. J Physiol (Lond) 224:421-440.

Eckert R, Tillotson DL (1981) Calcium-mediated inactivation of the calcium conductance in caesium-loaded giant neurones of Aplysia californica. J Physiol (Lond) 413:265-280.

Edmonds B, Klein M, Dale N, Kandel ER (1990) Contributions of two types of calcium channels to synaptic transmission and plasticity. Science 250:1142-1147.

Edstrom JP, Lukowiak KD (1985) Frequency-dependent action potential prolongation in Aplysia pleural sensory neurons. Neurosci 16: $451-460$.

Eliot LS, Kandel ER, Siegelbaum SA, Blumenfeld H (1993) Imaging terminals of Aplysia sensory neurons demonstrates role of enhanced $\mathrm{Ca}^{2+}$ influx in presynaptic facilitation. Nature 361:634-637.

Fossier P, Baux G, Tauc L (1994) N- and P-type $\mathrm{Ca}^{2+}$ channels are involved in acetylcholine release at a neuroneuronal synapse: only the N-type channel is the target of neuromodulators. Proc Natl Acad Sci USA 91:4771-4775.

Frazier WT, Kandel ER Kupfermann I, Waziri R, Coggeshall, RF (1967) Morphological and functional properties of identified neurons in the abdominal ganglion of Aplysia californica. J Neurophysiol 30: 1288-1351.

Furukawa Y, Kandel ER, Pfaffinger P (1992) Three types of early 
transient potassium currents in Aplysia neurons. J Neurosci 12:9891000.

Geduldig D, Gruener, R (1970) Voltage clamp ofthe Aplysia giant neurone: early sodium and calcium currents. J Physiol (Lond) 211:217244.

Gillette R, Gillette MU, Davis WJ (1980) Substrates of command ability in a buccal neuron of Pleurobranchaea. I. Mechanisms of action potential broadening. J Neurophysiol 43:669-685.

Gillette R, Kovac MP, Davis WJ (1982) Control of feeding motor output by paracerebral neurons in brains of Pleurobranchaea californica. J Neurophysiol 47:885-908.

Gola M, Crest M (1993) Colocalization of active K-Ca channels and $\mathrm{Ca}^{2+}$ channels within $\mathrm{Ca}^{2+}$ domains in Helix neurons. Neuron 10: 689-699.

Gola M, Hussy N, Crest M, Ducreux C (1986) Time course of Ca and $\mathrm{Ca}$-dependent $\mathrm{K}$ currents during molluscan nerve cell action potentials. Neurosci Lett 70:354-359.

Gola M, Ducreux C, Chagneux H (1990) $\mathrm{Ca}^{2+}$-activated $\mathrm{K}^{+}$current involvement in neuronal function revealed by in situ single-channel analysis in Helix neurons. J Physiol (Lond) 420:73-109.

Gorman AL, Thomas WV (1980) Potassium conductance and internal calcium accumulation in a molluscan neurone. J Physiol (Lond) 308: 287-313.

Hermann A, Erxleben C (1987) Charybdotoxin selectively blocks small Ca-activated $\mathrm{K}$ channels in an Aplysia neuron. J Gen Physiol 90:27-47.

Hermann A, Gorman ALF (1981a) Effects of 4-aminopyridine on potassium currents in a molluscan neuron. J Gen Physiol 78:63-86.

Hermann A, Gorman ALF (1981b) Effects of tetraethylammonium on potassium currents in a molluscan neuron. J Gen Physiol 78:87-110.

Howe JR, Ritchie JM (1991) On the active form of 4-aminopyridine: block of $\mathrm{K}^{+}$currents in rabbit schwann cells. J Physiol (Lond) 433: 183-205.

Jackson MB, Konnerth A, Augustine GJ (1991) Action potential broadening and frequency-dependent facilitation of calcium signals in pituitary nerve terminals. Proc Natl Acad Sci USA 88:380-384.

Kaang BK, Pfaffinger PJ, Grant SGN, Kandel ER, Furukawa Y (1992) Overexpression of an Aplysia shaker $\mathrm{K}^{+}$channel gene modifies the electrical properties and synaptic efficacy of identified Aplysia neurons. Proc Natl Acad Sci USA 89:1133-1137.

Katz B, Miledi R (1967) A study of synaptic transmission in the absence of nerve impulses. J Physiol (Lond) 192:407-436.

Kehoe J (1985) Synaptic block of a calcium-activated potassium conductance in Aplysia neurones. J Physiol (Lond) 369:439-474.

Koester J (1989) Chemically and electrically coupled interneurons mediate respiratory pumping in Aplysia. J Neurophysiol 62:1113-1126.

Lin JW, Faber DS (1988) Synaptic transmission mediated by single club endings on the goldfish mauthner cell. II. Plasticity of excitatory postsynaptic potentials. J Neurosci 8:1313-1325.

Llinas R, Sugimori M, Simon SM (1982) Transmission by presynaptic spike-like depolarization in the squid giant synapse. Proc Natl Acad Sci USA 79:2415-2419.

Lüscher HR, Shiner JS (1990) Simulation of action potential propagation in complex terminal arborizations. Biophys J 58:1389-1399.

Marom S, Levitan IB (1994) State-dependent inactivation of the KV3 potassium channel. Biophys J 67:579-589.

McCleskey EW (1994) Calcium channels: cellular roles and molecular mechanisms. Curr Opin Neurobiol 4:304-312.

Meech (1974) Prolonged action potentials in Aplysia neurons injected with EGTA. Comp Biochem Physiol 48A:397-402.
Mintz IM, Venema VJ, Swiderek KM, Lee TD, Bean BP, Adams ME (1992) P-Type calcium channels blocked by the spider toxin $\omega$-AgaIVA. Nature 355:827-829.

Mudge A, Leeman S, Fishbach GD (1979) Enkephalin inhibits release of substance $P$ from sensory neurons in culture and decreases action potential duration. Proc Natl Acad Sci USA 76:526-530.

Nerbonne JM, Gurney AM (1987) Blockade of $\mathrm{Ca}^{2+}$ and $\mathrm{K}^{+}$currents in bag cell neurons of Aplysia californica by dihydropyridine $\mathrm{Ca}^{2+}$ antagonists. J Neurosci 7:882-893.

Peng YY, Zucker RS (1993) Release of LHRH is linearly related to the time integral of presynaptic $\mathrm{Ca}^{2+}$ elevation above a threshold level in bullfrog sympathetic ganglia. Neuron 10:465-473.

Pfaffinger PJ, Furukawa Y, Zhao B, Dugan D, Kandel ER (1991) Cloning and expression of an Aplysia $\mathrm{K}^{+}$channel and comparison with native Aplysia $\mathrm{K}^{+}$currents. J Neurosci 11:918-927.

Pin T, Bessone R, Jacquet G, Gola M (1994) A wide-acting peptidergic interneurone in the snail Helix pomatia: graded recruitment and local firing of terminal processes. Comp Biochem Physiol 109A:83-99.

Quattrocki EA, Marshall J, Kaczmarek LK (1994) A Shab potassium channel contributes to action potential broadening in peptidergic neurons. Neuron 12:73-86.

Scroggs RS, Fox AP (1992) Calcium current variation between acutely isolated adult rat dorsal root ganglion neurons of different size. $J$ Physiol (Lond) 445:639-658.

Shapiro E, Castellucci VF, Kandel ER (1980) Presynaptic membrane potential affects transmitter release in an identified neuron in Aplysia hy modulating the $\mathrm{Ca}^{2+}$ and $\mathrm{K}^{+}$currents. Proc Natl Acad Sci USA 77:629-633

Smith SJ, Zucker RS (1980) Aequorin response facilitation and intracellular calcium accumulation in molluscan neurons. J Physiol (Lond) 300:167-196.

Spencer AN, Przysiezniak J, Acosta-Urquidi J, Basarsky (1989) Presynaptic spike broadening reduces junctional potential amplitude. $\mathrm{Na}-$ ture 340:636-638

Starzak ME, Starzak RJ (1978) An action potential clamp to probe the effectiveness of space clamp in axons. IEEE Trans Biomed Eng 25 201-204.

Thompson SH (1994) Facilitation of calcium-dependent potassium current. J Neurosci 14:7713-7725.

Tiaho F, Piot C, Nargeot J, Richard S (1994) Regulation of the frequency-dependent facilitation of L-type $\mathrm{Ca}^{2+}$ currents in rat ventricular myocytes. J Physiol (Lond) 477:237-251.

Trudeau LE, Baux G, Fossier P, Tauc L (1993) Transmitter release and calcium currents at an Aplysia buccal ganglion synapse. I. Characterization. Neuroscience 53:571-580.

Verhage M, McMahon HT, Ghijsen WEJM, Boomsma F, Scholten G, Wiegant VM, Nicholls DG (1991) Differential release of amino acids, neuropeptides, and catecholamines from isolated nerve terminals. Neuron 6:517-524.

Walsh JP, Byrne JH (1989) Modulation of a sleady-state Ca ${ }^{2+}$-activated, $\mathrm{K}^{+}$current in tail sensory neurons of Aplysia: role of serotonin and cAMP. J Neurophysiol 61:32-44.

Weiss KR, Chiel HJ, Kupfermann I (1986) Sensory function and gating of histaminergic neruon C2 in Aplysia. J Neurosci 6:2416-2426.

Westerfield M, Joyner RW, Moore JW (1978) Temperature-sensitive conduction failure at axon branch points. J Neurophysiol 41:1-8.

Yao JA, Tseng GN (1994) Modulation of 4-AP block of a mammalian A-type $\mathrm{K}$ channel clone by channel gating and membrane voltage. Biophy J 67:130-142.

Zucker RS (1993) Calcium and transmitter release. J Physiol (Paris) $87: 25-36$ 